Andrews University

Digital Commons @ Andrews University

2002

\title{
A Strategy for Evangelism Among the Bengali Folk Hindus of Calcutta
}

Eric Kujur

Andrews University

Follow this and additional works at: https://digitalcommons.andrews.edu/dmin

Part of the Practical Theology Commons

\section{Recommended Citation}

Kujur, Eric, "A Strategy for Evangelism Among the Bengali Folk Hindus of Calcutta" (2002). Professional Dissertations DMin. 470.

https://dx.doi.org/10.32597/dmin/470

https://digitalcommons.andrews.edu/dmin/470

This Project Report is brought to you for free and open access by the Graduate Research at Digital Commons @ Andrews University. It has been accepted for inclusion in Professional Dissertations DMin by an authorized administrator of Digital Commons @ Andrews University. For more information, please contact repository@andrews.edu. 


\section{ABSTRACT}

\section{A STRATEGY FOR EVANGELISM AMONG THE BENGALI FOLK HINDUS OF CALCUTTA}

by

Eric Kujur

Adviser: Gordon Christo 


\title{
ABSTRACT OF GRADUATE STUDENT RESEARCH
}

Dissertation

\author{
Andrews University \\ Seventh-day Adventist Theological Seminary
}

Title: A STRATEGY FOR EVANGELISM AMONG THE BENGALI FOLK HINDUS OF CALCUTTA

Name of the researcher: Eric Kujur

Name and degree of faculty adviser: Gordon Christo, Ph.D.

Date completed: October 2001

The purpose of this study was to develop a strategy to reach the unreached Bengali Folk Hindus of Calcutta.

First, general information on the target group was presented. This included information on their lifestyle and traditional religious beliefs and practices. This is a large group of people who do not belong to the castes and do not enjoy the benefits of financial, educational, and political status.

A brief review of what Roman Catholic and Protestant churches have done for the Folk Hindus of Calcutta, with their medical, educational, spiritual, and social services, helped us to understand the strengths and weaknesses of mission approaches to the target group. It also helped us to know their resistance and receptivity to the gospel. Further, the barriers of the target group are listed and clarified.

The evangelistic strategy planned to reach this target group in the Calcutta area includes organization of evangelistic teams, tapping existing resources to assist the 
people to meet their felt needs, and building bridges by means of social, medical, and educational endeavors. Finally, the Folk Hindus of Calcutta should hear the gospel presented to them, with special emphasis on Jesus as the only way to God and as the source of equality for all peoples. The power of God to heal and confront the spirits should also be emphasized, together with the importance of the Bible. Folk Hindus need to be made aware of the need for individual accountability before God, after which they can be led to baptism as an outward sign of their desire to follow Jesus. Once they have been baptized, they must be nurtured in fellowship, discipleship, and missionary work. 
Andrews University

Seventh-day Adventist Theological Seminary

\title{
A STRATEGY FOR EVANGELISM AMONG THE \\ BENGALI FOLK HINDUS OF CALCUTTA
}

\author{
A Dissertation \\ Presented in Partial Fulfillment \\ of the Requirements for the Degree \\ Doctor of Ministry
}

by

Eric Kujur

January 2002 

A STRATEGY FOR EVANGELISM AMONG THE

BENGALI FOLK HINDUS OF CALCUTTA,

A dissertation

presented in partial fulfillment

of the requirements for the degree

Doctor of Ministry

by

Eric Kujur

APPROVAL BY THE COMMITTEE:

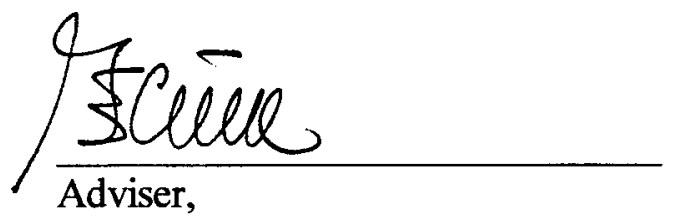

Gordon Christo
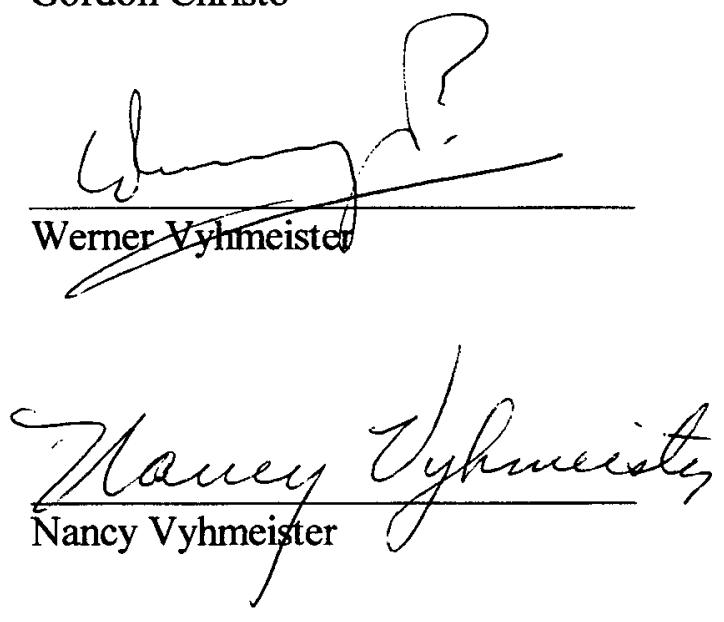
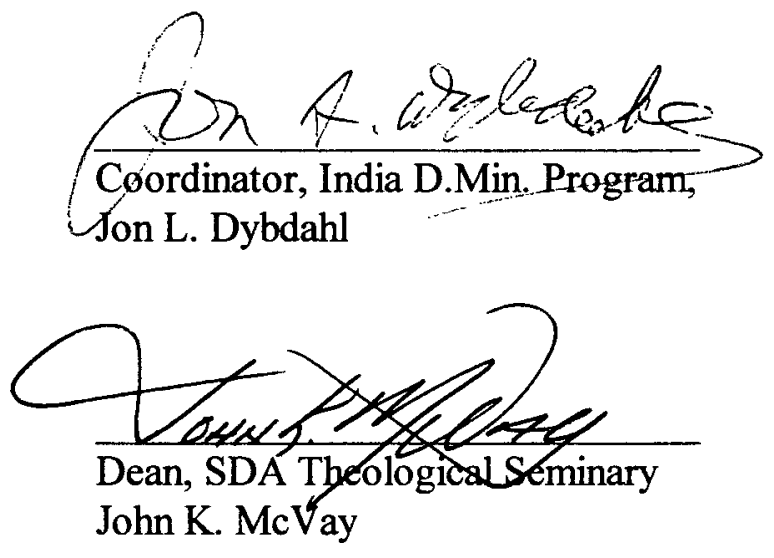

$3-1-2002$

Date Approved 


\section{TABLE OF CONTENTS}

LIST OF TABLES $\ldots \ldots \ldots \ldots \ldots \ldots \ldots \ldots \ldots \ldots \ldots \ldots \ldots \ldots$

ACKNOWLEDGMENTS $\ldots \ldots \ldots \ldots \ldots \ldots \ldots \ldots \ldots \ldots \ldots \ldots$ vii

\section{Chapter}

1. INTRODUCTION $\ldots \ldots \ldots \ldots \ldots \ldots \ldots \ldots \ldots \ldots \ldots \ldots \ldots \ldots$

Statement of the Task $\ldots \ldots \ldots \ldots \ldots \ldots \ldots \ldots \ldots \ldots \ldots$

Justification of the Project $\ldots \ldots \ldots \ldots \ldots \ldots \ldots \ldots \ldots \ldots \ldots$

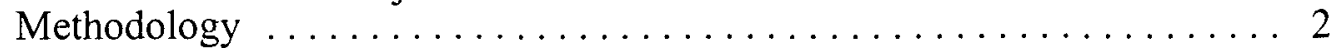

Overview of the Dissertation $\ldots \ldots \ldots \ldots \ldots \ldots \ldots \ldots$

2. DESCRIPTION OF THE TARGET PEOPLE $\ldots \ldots \ldots \ldots \ldots \ldots \ldots \ldots$

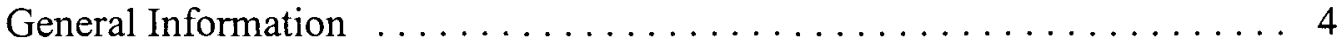

Calcutta and Its Location ..................... 4

History and Population of Calcutta ................ 4

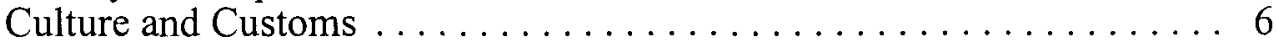



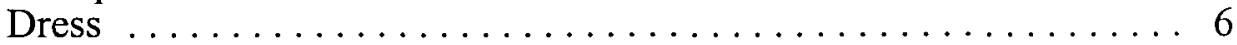

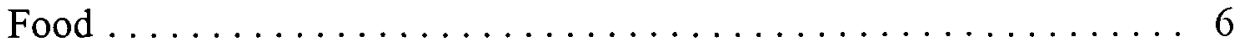

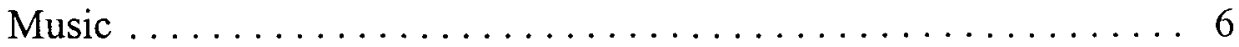

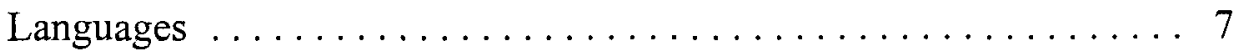

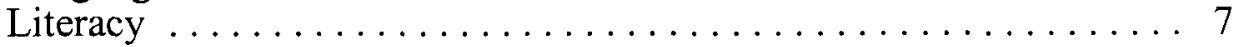

Health and Sanitation $\ldots \ldots \ldots \ldots \ldots \ldots \ldots \ldots \ldots$

Economic Status . . . . . . . . . . . . . . . . . 10

Political Status . . . . . . . . . . . . . . . . . . 10

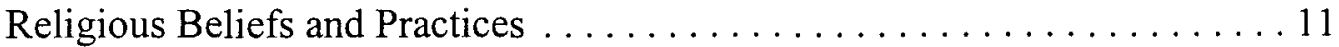

Beliefs and Rites . . . . . . . . . . . . . . . . . . . 11

Nature Gods . . . . . . . . . . . . . . . . . . . . . . . . . 14



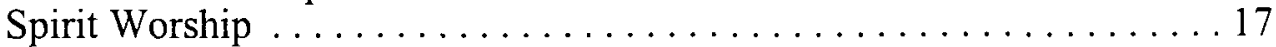

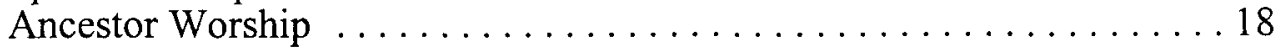

Principal Deities . . . . . . . . . . . . . . . . . . . 19

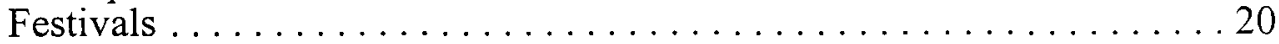

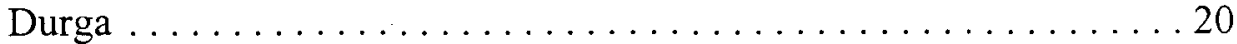

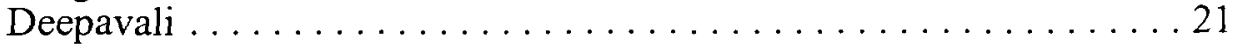

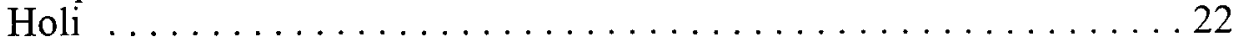

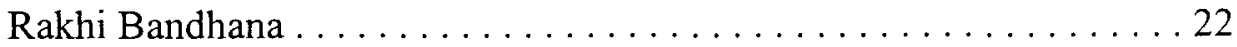

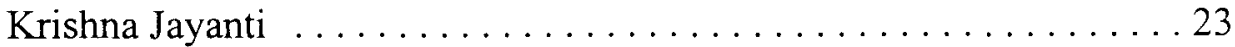

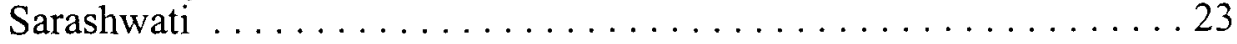




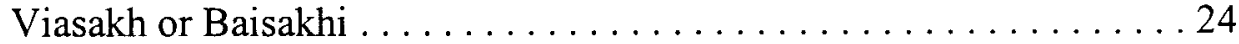

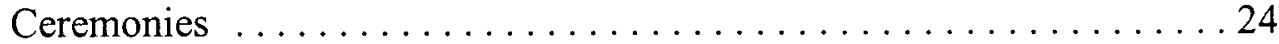



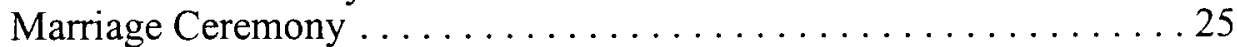

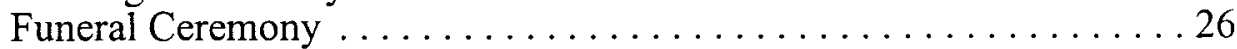

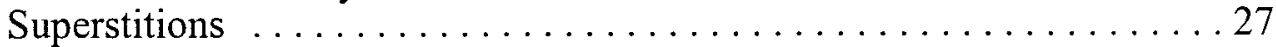



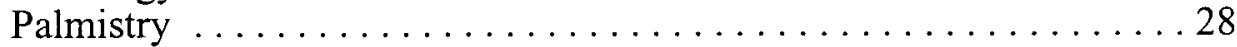

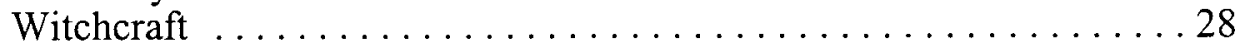



Maya ................................... 29

3. CONTRIBUTIONS OF CHRISTIANITY AND THE

RESPONSE OF BENGALI FOLK HINDUS $\ldots \ldots \ldots \ldots \ldots \ldots \ldots \ldots \ldots$

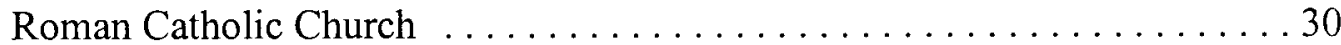

Protestant Missions ... . . . . . . . . . . . . . . . . . . 33

Contributions of William Carey (1751-1834) and the Baptists . . . . . 33

Contributions of Alexander Duff $(1806-1878) \ldots \ldots \ldots \ldots 34$

Contributions of the Assembly of God Ghurch . . . . . . . . . . 35

Contributions of the Church of North India . . . . . . . . . . . 36

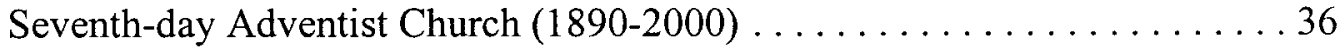

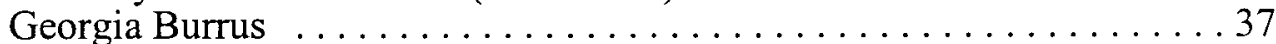

Church Development . . . . . . . . . . . . . . . . . . . . 38

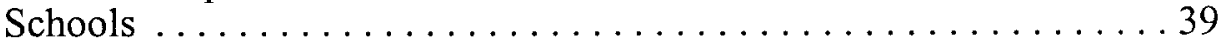

Orphanage ......................... 41

Publishing Work ....................... 41



SDA Work in Arambagh . . . . . . . . . . . . . . . . . . 42

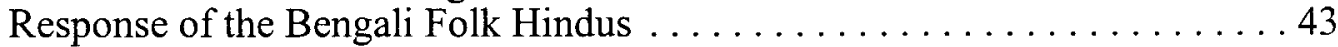

Resistance ............................ 44

Receptivity ......................... 45

4. BARRIERS AND BRIDGES TO EVANGELISM OF FOLK HINDUS $\ldots \ldots 47$

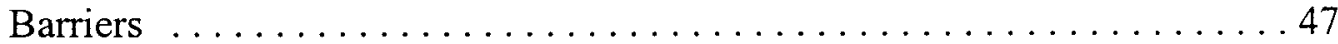

Concept of Many Ways . . . . . . . . . . . . . . . 47

Caste System . . . . . . . . . . . . . . . . . . . . . . 47



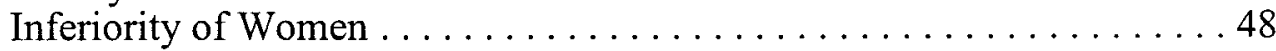

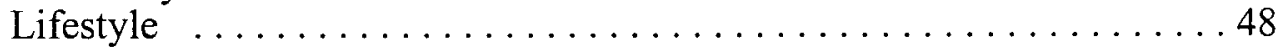

Illiteracy and Ignorance $\ldots \ldots \ldots \ldots \ldots \ldots \ldots \ldots \ldots \ldots \ldots$

Poverty ................................ 49

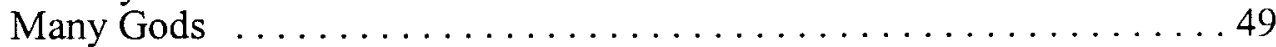

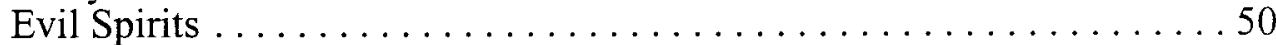

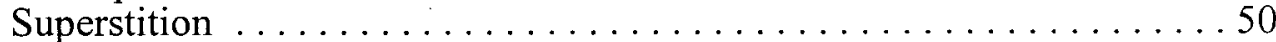



Bridges . . . . . . . . . . . . . . . . . . . . . . 51 




Preevangelism Approaches $\ldots \ldots \ldots \ldots \ldots \ldots \ldots \ldots \ldots \ldots \ldots \ldots$

Committees .................................. 55

Orientation and Training of the Team $\ldots \ldots \ldots \ldots \ldots \ldots \ldots \ldots \ldots$



Survey of the Target People . ...................... 58

Tapping Resources to Meet Felt Needs $\ldots \ldots \ldots \ldots \ldots \ldots \ldots \ldots \ldots \ldots$

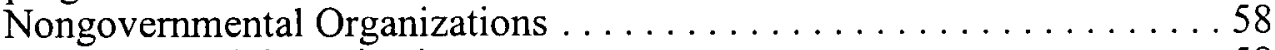

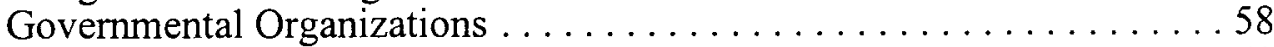



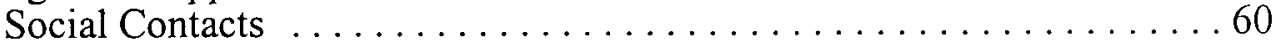

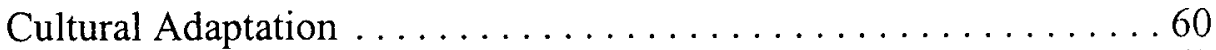

Clubs .................................62

Dialogue .............................63



Medical Contacts ...............................64 64

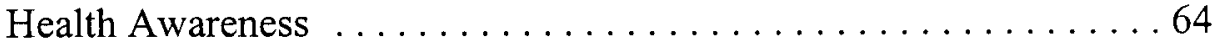

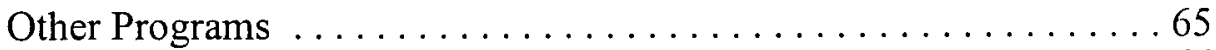

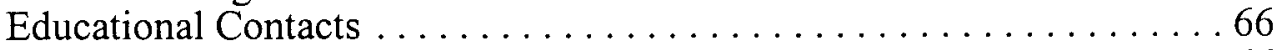



Adult Education . . . . . . . . . . . . . . . . . . . . . 66

Religious Contacts . ..........................67 67

Jesus: The Only Way to God's Love . . . . . . . . . . . . . . . 67

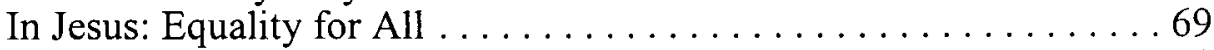

The Super Power of God $\ldots \ldots \ldots \ldots \ldots \ldots \ldots \ldots \ldots \ldots \ldots \ldots$

The True Word of God . . . . . . . . . . . . . . . . . . . . . . 72

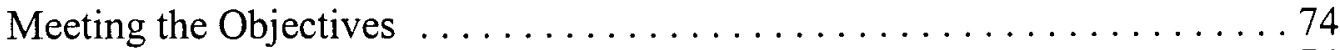

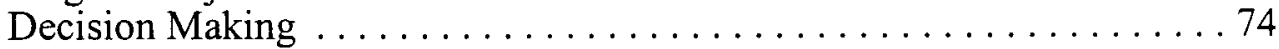

Baptism Encounter ............................. 75



6. SUMMARY, CONCLUSIONS, AND RECOMMENDATIONS ......... 78



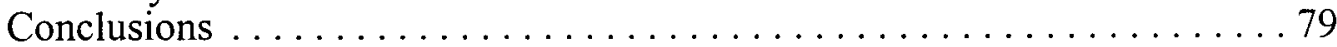

Recommendations ............................. 79

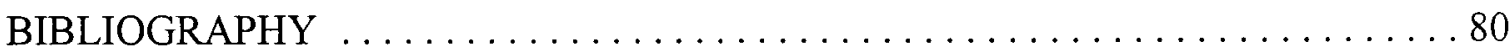

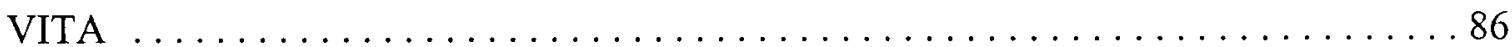




\section{LIST OF TABLES}

1. Churches and Other SDA Institutions in Calcutta $\ldots \ldots \ldots \ldots \ldots \ldots$

2. Literacy Rates, Calcutta, $1951-1981 \ldots \ldots \ldots \ldots \ldots \ldots \ldots$

3. Religious Affiliation in Calcutta $\ldots \ldots \ldots \ldots \ldots \ldots \ldots \ldots \ldots \ldots \ldots \ldots$

4. Roman Catholic Institutions and Their Growth (1920-1977) in Bengal . . . 31

5. Roman Catholic Presence in Bengal, $1998 \ldots \ldots \ldots \ldots \ldots \ldots \ldots \ldots$

6. Roman Catholic Health and Welfare Activities, $1998 \ldots \ldots \ldots \ldots \ldots$

7. Roman Catholic Educational Institutions, $1998 \ldots \ldots \ldots \ldots \ldots \ldots$

8. Pastors and Church Membership of the Seventh-day Adventist English Church . . . . . . . . . . . . 40

9. SDA Institutions in the Calcutta Area $\ldots \ldots \ldots \ldots \ldots \ldots \ldots \ldots \ldots$

10. Similarities between Bengali Folk Hinduism and Christianity $\ldots \ldots \ldots 51$

11. Dissimilarities between Bengali Folk Hindus and Christians . . . . . . . 52 


\section{ACKNOWLEDGMENTS}

To my family:

My beloved wife, Mercy, supported me with great concern and earnest prayers. Praise God that He extended my life to serve Him for more years because of her fervent

prayers. I praise God for a good wife, and two children, Melinda and Eddie, who missed many opportunities of being with their father. They understood the value of my study and supported me with their prayers.

To my professors:

Dr. Gordon Christo, who humorously pressed and encouraged me to be optimistic. Dr. Bruce and Linda Bauer who, with Christian love, helped me to move forward with my study. Drs. Nancy and Werner Vyhmeister and Dr. Jon Dybdahl who guided with paternal care. I also owe much to all the professors who were sent by Andrews University.

To my employing organization:

Dr. M. E. Cherian, who envisioned the dream and motivated us. Pastor D. R. Watts and the Southern Asia Division board members who supported and encouraged us towards the study. Pastors P. D. Kujur, S. D. Kujur, S. G. Mahapure, and all other officers who encouraged me along with the West Bengal and Bihar Section officers who patiently dealt with and supported my study.

To the faculty of Spicer Memorial College:

Drs. Samuel and Prema Gaikwad, Mr. Noble Pilli, Dr. and Mrs. Patrick Manu, Mr. and Mrs. S. Solomon, Mr. and Mrs. D. R. Kindo, and Mr. and Mrs. Nigel Soreng. To all of them I express my deep appreciation for what they have done during my study. 
To the Almighty God who provided opportunity, wisdom, health, and strength to work and do my research with the heavy burden of work loads and transfers. Praise and honor to God. I dedicate this dissertation for His glory and advancement of His commission. 


\section{CHAPTER 1}

\section{INTRODUCTION}

\section{Statement of the Task}

The task of this dissertation is to develop a suitable strategy for evangelism among the unreached Bengali Folk Hindus of Greater Calcutta, West Bengal, India.

\section{Justification of the Project}

The target people, Bengali Folk Hindus, are in the grip of traditional beliefs and practices of Hinduism and animism. The traditional beliefs and practices have blinded them to the gospel truth. This paper suggests methods that supercede traditional or Western evangelistic methods. The strategy presented here has been tried in a limited way, and has proven to be effective in evangelizing the target group. It meets their felt needs. A fuller development of the strategy is now needed.

The Seventh-day Adventist (SDA) Church has been in Calcutta for more than eleven decades without much progress. There are, at present, in Calcutta, only three churches and two companies. Table 1 shows information on the Adventist presence in Calcutta.

Nearly fifteen million Hindus live in Calcutta. A large segment among them are Folk Hindus. Many Folk Hindu Bengalis suffer from sickness, poverty, malnutrition, ignorance, illiteracy, exploitation, a poor lifestyle, the evil practices of society, and traditional religious beliefs. It is anticipated that the holistic Seventh-day Adventist message, lived within their cultural setting and presented in a simple manner, will be effective in reaching Folk Hindu Bengalis in Calcutta. 
TABLE 1

CHURCHES AND OTHER SDA INSTITUTIONS IN CALCUTTA

\begin{tabular}{llc}
\hline $\begin{array}{l}\text { Churches and Other } \\
\text { Institutions }\end{array}$ & Number & Members/Students \\
\hline Companies & 2 & 63 \\
Churches & 3 & 110 \\
Elementary Schools & 3 & $400^{*}$ \\
High School & 1 & $600^{*}$ \\
Orphanage & 1 & 21 \\
Seminary & 1 & 3 \\
\hline
\end{tabular}

* SDA students are 1.00 percent.

\section{Methodology}

Research on this dissertation topic has been done in a number of libraries and study centers in Pune, Madhupur, Bihar, and Calcutta.

A review of selected literature on missionary movements and social reform has been undertaken, including studies on William Carey, Alexander Duff, Raja Ram Mohan Roy, Swami Vivekananda, and Mother Teresa.

Some prominent and experienced traditional Bengali Folk Hindus and Christian leaders have been interviewed with the following purposes:

1. To acquaint myself with their culture

2. To learn more about their language and dialects

3. To gather detailed information regarding their religious beliefs and practices

4. To know their attitude towards Christianity and its contributions in the fields of education, medicine, and social welfare

5. To understand and develop a mutual relationship

6. To prepare a suitable strategy for evangelism to the target group. 
3

\section{Overview of the Dissertation}

Chapter 1 introduces the dissertation. Chapter 2 provides general information on the target group, and their religious beliefs and practices. Chapter 3 deals with contributions of Christian missionaries and the reactions of Hindus towards Christianity. Chapter 4 examines lifestyle, beliefs, and practices of the target group. Chapter 5 describes the suggested strategy for evangelistic approaches. Chapter 6 includes the summary, conclusions, and recommendations. 


\section{CHAPTER 2}

\section{DESCRIPTION OF THE TARGET PEOPLE}

This chapter provides an overview of Greater Calcutta, its culture and customs, and a more detailed description of the Folk Hindus, their religious beliefs and practices.

\section{General Information}

Calcutta and Its Location

Calcutta is located on the east side of the river Ganges (called Hooghly in

Calcutta). It is situated at longitude 88.23 degrees east, and latitude 22.33 degrees north.

The surrounding areas are covered with lowlands and swamps, $160 \mathrm{kms}$ north from the

Bay of Bengal. These areas are not healthy for habitation.

\section{History and Population of Calcutta}

The following sketchy history of Calcutta begins before the arrival of the British.

In the sixteenth century, when Portuguese traders commenced operations in Bengal, the two great centers of maritime trade there were Chattagram or Chittagong (Porto Grande or the 'Great Harbor') and Saptagram or Satgaon (Porto Piqueno or the 'Little Harbor'). The latter now is an insignificant village northwest of Chunchura.

In the late sixteenth century, the great majority settled at Hooghly, a Portuguese settlement since the late fifteenth century, dominated from the 1630's by the Dutch, the leading European trader in Bengal at the time. ${ }^{\prime}$

Calcutta was founded in 1690 by Charnock, who was an agent of the East India Company. There were three small villages in the area and Charnock chose one of them

'Sukanta Chaudhuri, Calcutta the Living City, 2 vols. (Calcutta: Oxford University Press, 1990), 1:3. 
for British trade settlement. It was then named "Kalikatta."

As time passed the city developed. "Calcutta became the capital of India in 1773. By 1900 Calcutta ranked second only to London as the largest city in whole British Empire."

As a result of India's struggle for independence (mid-twentieth century), many displaced people moved to Calcutta, overcrowding the city. The city has seen much violence, both political and religious. "In 1946 a riot between Hindus and Muslims over the proposed division of India into two nations left 4,000 people dead on the city streets. Riots against the government occurred frequently in Calcutta during the 1960s and 1970s." 3

The population grew due to migration from rural areas. Already in 1970 Ashok Mitra wrote that "the city's physical growth and extension in the last four years call for anxious reappraisal."

The population of Calcutta proper, according to the 1991 census, was 4,399,819, of which $2,443,328$ were males and $1,954,491$ females. ${ }^{5}$ At the same time the population of Greater Calcutta was nearly 11 million. In 2000 the population of Greater Calcutta was estimated at nearly 16 million inhabitants, making it the largest city in India. ${ }^{6}$

'The New Book of Knowledge, 1975, s.v. "Calcutta."

${ }^{2}$ The World Book Encyclopedia, 1996, s.v. "Calcutta."

${ }^{3}$ Ibid., 4 .

${ }^{4}$ Asok Mitra, Calcutta on the Eve of Her Tercentenary (New Delhi: Abhinav Publications, 1990), 122.

${ }^{5}$ S. C. Bhatt, ed., The Encyclopedic District Gazetteers of India (New Delhi: Gyan Publishing House, 1998), 9:839.

6"Calcutta: Not the City of Joy," http://cesimo.ing.ula.ve/GAIA/CASES/ IND/CAL/main.html (30 June 2001). 


\section{Culture and Customs}

Calcutta is as green and colorful as its environment, including ethnic groups from a variety of national and international backgrounds. Many expatriates remained after the independence of India: British, Portuguese, Burmese, Dutch, Parsees, Armenians, Chinese, and others. People have also migrated there from all states of India.

\section{Occupations}

The majority of the people are laborers, fishermen, small merchants, potters, washermen, rickshaw pullers, cleaners, sweepers. Naturally, in a large city there are also office workers and wealthy businessmen. About 35 percent of the population is considered to be living in substandard conditions. ${ }^{1}$

\section{Dress}

The men generally wear the kurta (a long sleeved shirt) and pajama (long, loose pants) or dhoti (a long, loose cloth strip around their waist). The women wear sarees (a long strip of printed or plain cloth around their waist) with a blouse.

\section{Food}

The common foods that people eat are rice, dal (legumes), chapati (a flat unleavened bread), with some vegetables, and fish. Sweets are the dessert eaten after the main meal. The guests are entertained with special sweet rasgullas. They enjoy the delicacy of tender coconut and palm date juice, called tari, a drink that ferments if kept until the next day.

\section{Music}

The Bengalis love songs, dances, and Kritan-Bhajan, an all-night program of group and solo vocal singing with music, dramas, and entertainment. "These musical and

\footnotetext{
"Calcutta: Not the City of Joy."
} 
cultural programs are organized by the communities," said Mr. Mondal in an interview.'

\section{Languages}

The major language of the Bengalis is Bengali. Hindi, Urdu, Punjabi, English, Marwari, Gujarati, and other languages are also spoken. The target group speaks Bengali, a language spoken by more than 44 million people in West Bengal. ${ }^{2}$

\section{Literacy}

Traditional Bengalis do not like to have their daughters educated. The female child has traditionally been considered inferior. The trend is changing slowly now. "For a metropolitan city, Calcutta has a shamefully low rate of literacy among the male as well as the female population." The low literacy rate for women, as shown in table 2 , is due to the traditional attitude of society. However, a growth from 43 percent to 63 percent is evident.

S. C. Bhatt points to the high level of literacy in Calcutta, second only to Kerala. In 1991 almost 80 percent were literate. Of these, 1,260,703 were females and 1,827,195 were males. That makes a literacy rate of 72.09 percent for females and 81.94 percent for males. $^{4}$

In 1964 Calcutta already had 2 universities, 150 colleges, 32 medical institutions, 126 high and higher secondary schools, 254 primary schools, and 160 libraries. ${ }^{5}$ The number of educational institutions has since grown. $9,1999$.

'S. Mondal, Folk Hindu converted to Adventism, interview by author, November

${ }^{2}$ Albert S. Vasantharaj, A Portrait of India (Madras: Church Growth Association of India, 1995), 30.

${ }^{3}$ Chaudhuri, 2:45.

${ }^{4}$ Bhatt, 9:843.

${ }^{5}$ B. N. Kumar, Calcutta 1964 (Calcutta: Lalvani Publishing House, 1968), 42. 
The need to educate their children is the greatest challenge to the urban dwellers who seek a better living.

TABLE 2

LITERACY RATES, CALCUTTA, 1951-1981

\begin{tabular}{lllllll}
\hline \hline & \multicolumn{2}{l}{ Number of Males } & \multicolumn{2}{l}{ Number of Females } & \multicolumn{2}{l}{ Literacy \% } \\
\hline Year & Total No. & Literate & Total No. & Literate & Male & Female \\
1951 & $1,623,211$ & 952,154 & 925,466 & 401,185 & 59 & 43 \\
1961 & $1,805,383$ & $1,154,012$ & $1,109,020$ & 581,443 & 64 & 52 \\
1971 & $1,924,505$ & $1,233,257$ & $1,224,241$ & 665,988 & 64 & 54 \\
1981 & $1,930,620$ & $1,418,245$ & $1,374,686$ & 866,247 & 73 & 63 \\
\hline
\end{tabular}

Source: Sukanta Chaudhuri, Calcutta the Living City (Calcutta: Oxford University Press, 1990), 2:46.

Health and Sanitation

The urban dwellers live a better and healthier life than rural dwellers due to certain facilities and sanitation provided by metropolitan Calcutta. Medical facilities such as hospitals, clinics, dispensaries, first-aid boxes, ambulances, and other medical mobile resources help to provide good health care. Transportation is good, clean, fast, and easily accessible in all directions. Calcutta is the center of airways, railways, and navigations. Emergency facilities such as fire extinguishers, fire brigades, police, and emergency medical services provide 24-hour service. Garbage dumps, drainage, toilets, dust bins, garbage cans, and water facilities are provided to keep the city clean. Advertisements and sign boards (such as, "Green Calcutta," "Keep the City Clean," and "Use Me") help the people to be aware of and make use of the facilities provided.

In spite of their advantages, city dwellers are unhealthy and fall sick often. They suffer from many health problems, such as typhoid, jaundice, malaria, diarrhea, cholera, respiratory problems, heart disease, scabies, and other skin diseases. The cause of these 
problems is overcrowding in homes, slum living, poor sanitation and toilet facilities, inadequate and/or dirty drinking water, open garbage dumps, open drainage with improper outlets, footpath canteens, and food stalls handled in unhygienic ways.

Geoffrey Mott wrote about health-care facilities:

Mother Teresa's nuns are also almost the only people who care for Calcutta's lepers and those are reckoned to be something between 35,000 to 40,000 . Of those, with one exception the hospitals cannot or will not take them and when the police finds a leper wondering at night in the rich suburbs of Alipore, it is the missionary convent they ring for a truck to convey the wretch out of the way. ${ }^{1}$

The 1996 World Book noted: "Although there are more than forty hospitals and a large number of doctors, Calcutta's medical facilities are overstretched."'2 Patrick Johnstone points out:

Calcutta is a huge and tragic slum with the lowest urban standard of living in the world. It is named after the Hindu deity Kali, the goddess of destruction. Pray for the destruction of Satan's kingdom there, pray also for Catholics and Evangelicals alike who seek to share their faith in squalid slums where 4.5 million people live, and in streets where a further million eke out an existence. Only 45 of the 163 congregations in the city are Bengali-speaking. ${ }^{3}$

Pollution constitutes one of the greatest hazards for urban dwellers in general, and for the population of Calcutta in particular. It may take a variety of forms: air pollution, noise pollution, food and/or water contamination, or environmental pollution.

Lifestyle problems are caused by individual, social, and traditional bad habits such as smoking, drinking alcohol, chewing tobacco and betel nut, and taking drugs. In addition, the heavy consumption of soft drinks, fast food, ice creams, and sweets hinders health. Health awareness and good health programs can promote better life and considerably reduce the health hazards. 1971), 77.

'Geoffrey Mott, Calcutta: The City Revealed (New Delhi: Penguin Books India, 2The World Book Encyclopedia, 1996, s.v. "Calcutta."

${ }^{3}$ Patrick Johnstone, Operation World (Carlisle, UK: OM Publishing, 1993), 291. 


\section{Economic Status}

Many millions have been attracted to Calcutta because of the opportunities for business, trade, technology, transportation, education, work, and communications. Thousands of industries and big factories are booming. Thousands of professionals and millions of laborers are employed here. Calcutta and its people are expanding because of present economic conditions.' According to Chaudhouri, "From the present trend it seems to be almost certain that the 'outgrowth' area surrounding Calcutta will go on expanding."

Life in Calcutta is not free from tension between the skyscrapers and the dirty slum dwellers, between luxury and pavement dwellers. Yet life goes on.

\section{Political Status}

Bengalis are patriotic. They support party politics. Many national freedom fighters are from this land.

It is generally agreed that India's independence movement started in Bengal, and numerous Bengalis were the first Indians to take active part in this movement. Thousands of Bengalis offered their lives in order to gain freedom from the power of the British crown. ${ }^{3}$

By nature Bengalis are revolutionists. Among the most prominent are leaders such as Netajee Subhash Chandra Bose, Surender Nath Banerjee, Jagdish Chandra Bose, Raja Ram Mohan Roy, Rabindra Nath Tagore, Aurobindoo Ghosh, and Swami Vivekananda. Some of these were reformers who contributed to society and the nation.

${ }^{1}$ Chaudhuri, 2:97.

${ }^{2}$ Ibid.

${ }^{3}$ Thankappan Nair, The People of Calcutta (Calcutta: National Fellowship, n.d.), 2. 


\section{Religious Beliefs and Practices}

According to the 1991 census, the religious affiliation of 78 percent of the population of the Calcutta district was Hinduism; another 20 percent were Muslim. Christians were only 0.57 percent of the total. ${ }^{1}$ This information is shown in table 3 .

TABLE 3

RELIGIOUS AFFILIATION IN CALCUTTA

\begin{tabular}{lrc}
\hline \hline Affiliation & Number & Percentage \\
\hline Hindus & $3,546,431$ & 78.00 \\
Muslims & 779,433 & 20.00 \\
Christians & 38,155 & 0.57 \\
Sikhs & 15,786 & 0.08 \\
Buddhists & 6,171 & 0.27 \\
Jains & 13,053 & 0.07 \\
Others & 757 &.-- \\
Religion not stated & 33 &.-- \\
\hline
\end{tabular}

Beliefs and Rites

Folk Hinduism falls under the great umbrella of Hinduism, which is one of the oldest living religions. ${ }^{2}$ Folk Hinduism has adopted beliefs and practices from all around, particularly from Hinduism and animism. "Hence it is closely connected with the mythology, the folklore, and the customs and manners of Hindus, making it rather difficult to distinguish its essentials from non-essentials."

Since Folk Hindus are not identified separately, it is hard to present statistics regarding them. There is no demarcation or line that separates Folk Hindus from

\section{'Bhatt, 9:840.}

${ }^{2} \mathrm{~K}$. W. Morgan, The Religion of the Hindus (New York: Ronald Press, 1953), 11.

${ }^{3}$ Ibid., 11 . 
Hinduism at large. According to Projesh Banerji, "In a primitive community the whole body of persons comprising it is the 'folk' and in the best sense of the word it might be applied to the entire population of any community."

Folk Hinduism is also termed "popular Hinduism" or "rural Hinduism." Albert S. Vasantharaj describes it as follows:

Popular Hinduism is the religion of the unprivileged masses of India. It has belief in a god or goddess in many forms associated with every aspect of life. The belief appears to be a mass of fables and superstitions. It has no organized means for religious education and focuses on nature worship and frequent festivals. ${ }^{2}$

There are many Folk Hindus in every segment of people in Calcutta. In each of these, ideology, customs, beliefs, and practices differ from the main stream of Hinduism. This is affirmed by Whitehead: "The village duties and their worship are widely different from the popular Hindu deities Shiva and Vishnu and worship that centers in the great Hindu temple."

There may be some similarities in the names of their deities but they may differ in beliefs and practices. More often the religions are moved by the religious leaders, as affirmed by N. C. Choudhury: "In fact the folk-Hinduism gains momentum on the sway of the popular prophets." ${ }^{\prime 4}$

Further, N. C. Choudhury adds that village-type religion is accepted locally because it satisfies local society and has developed within their needs and cultural bed. ${ }^{5}$ Thus their beliefs and practices are formed by their daily lives.

'Projesh Banerji, Folk Dances of India (Allahabad: Kitabistan, 1944), 10.

${ }^{2}$ Vasantharaj, 14.

${ }^{3} \mathrm{H}$. Whitehead, The Religious Life of India (Calcutta: Association Press, 1921), 17.

${ }^{4}$ N. C. Choudhury, Hinduism: A Religion to Live By (New Delhi: B. I. Publications, 1979), 141.

${ }^{5}$ Ibid. 
William Bascom finds that myths are basically religious. They help to understand matters of religion in their daily experiences so they are "sensational." Since the Folk Hindu beliefs and practices are related to native culture and customs, their identity remains locally within their community. It may differ from place to place and culture to culture.

Some factors concerning Folk Hinduism are significant. The following list comes from conversations with Folk Hindus around Calcutta over a period of several years.

1. A part of Hinduism, it has definite ties with animism.

2. It is confined to native communities.

3. It is associated with the nature worship of animism.

4. It attracts middle and low caste people.

5. It has no large shrines or temples.

6. It has no definite history or origin.

7. It has no founder, but has society.

8. It has no written or oral creeds or doctrines.

9. It has no set priests yet the worshippers call their leaders pujaries (priests).

10. It has rituals and sacrifices to deities.

11. It has polytheistic ideas.

12. It is aware of malevolent and benevolent spirits.

13. Spirits are feared and worshiped to make appeasement.

14. It has no concept of a high deity, hell, heaven, judgment, or eternal reward.

15. It uses blood sacrifice for appeasement, forgiveness of sins, and prosperity.

16. It has high regard for magic and myths.

17. It is superstitious.

'William Bascom, "The Forms of Folklore: Prose Narratives," Journal of American Folklore 78 (1965): 4. 
The target Folk-Hindu groups of Calcutta are attracted to folklore, dances, songs, and drama. They love to attend at any cost and support these performances wholeheartedly. They greatly enjoy such activities. In fact there is much demand for such folk activities that reflect their way of life. Agarkar highlights that these folk dances were earlier used by families but now have become public functions. Whenever an idol is brought into a place in a house, there is a great celebration, festivity, music, and dances.'

\section{Nature Gods}

Because Folk Hindus unite Hinduism and animism, they are inclined towards nature worship.

Earth is called Dharti Mata "Mother Earth," the most venerable of all objects. They believe that everything came out of the earth, goes into it, and that the earth is basic for all productivity. Earth is also a symbol of fertility. It is believed to have given birth to all creatures and vegetation. ${ }^{2}$

Not only is the earth subject to purification and sacrifice, but it is the source of all fertility. Mother earth is compared to a woman who conceives and gives birth to a child. ${ }^{3}$ Out of respect to this mother earth goddess the farmers do not plough their fields on Thursdays. Thomas states: "Earth is a symbol of patience, bearing all the misdeeds of men which are absorbed in earth, therefore, they worship mother earth reverently."

W. Crook points out: "When a cow or buffalo is first bought or when she first gives milk after calving, the first fine streams of milk drawn from her are allowed to fall 72.

'A. J. Agarkar, Folk Dances of Mahabharata (Bombay: L. N. Chapekar, 1950),

${ }^{2}$ P. K. Agarwala, Goddesses in Ancient India (New Delhi: Abhinov Publications, 1984), 88.

${ }^{3}$ Ibid.

${ }^{4}$ Paul Thomas, Epics, Myths, and Legends of India (Bombay: D. B. Taraporevala Sons, n.d.), 88. 
on the ground in honor of the goddess and every time of milking the first stream is so treated." I have seen some Folk Hindus let the first streams of milk flow to the ground every time they milk their cows, thus paying respect/reverence to Dharti-Mata (mother earth). I have also witnessed them offering water, milk, flower petals, or grains by pouring them out to the ground. They also believe that the ground is always holy.

Other nature objects are also worshiped by the Folk Hindus. I present only the name and meaning of these objects. These I have collected from my oral interviews with several people, as they believe the supreme god to be subject to nature forces.

Indira is considered the god of the sky, of thunder, lightning, storms, and rains. ${ }^{2}$ Another name for this is Vaya. Agni is the god of fire. ${ }^{3}$ Surya is the sun god, universal creator, and source of all living creatures. With the light of the sun all are sustained. ${ }^{4}$ Yoma is the god of the underworld, the Hindu god of death; Samsan, more specifically, is the deity of the grave. ${ }^{5}$

Trees are the dwelling place of spirits, in particular the Badd (Banyan) tree. The Pipal tree (Ficus Bengalica India), Tulsi, Darbha grass, and other plants are venerated by Folk Hindus.

Rivers are considered beneficial, but may also be malevolent when floods kill thousands of people. The worship of river gods is to appease them so there will not be destruction or calamity. Not only the Ganges River, but also all other rivers are worshiped locally. The people consider that ritual bathing makes them holy.

\footnotetext{
${ }^{1} \mathrm{~W}$. Crook, The Popular Religion and Folklore of Northern India (Delhi: Musiram Manoharlal Oriental Publishing, 1996), 26. 1975), 32.

${ }^{2}$ Donald H. Bishop, Indian Thought: An Introduction (New Delhi: Wiley Eastern,

${ }^{3}$ Ibid.

${ }^{4}$ Ibid., 148.

${ }^{5}$ Alexander Campbell, The Heart of India (New York: Knopf, 1958), 145.
} 
Niharranjan Ray, in his History of the Bengali People, writes that "the influence of folk religion is also very strong at the root of Ganga-Yamuna' concepts."2

Rocks and unusually shaped stones are greatly venerated and worshipped everywhere. They are normally placed in a natural open space, under the trees, or in specially built small shrines.

Fetishism is common among the Folk Hindus. Unusual shapes and objects are considered to be the abode of spirits and thus worshiped to avoid the curse of evil spirits.

\section{Animal Worship}

Cow worship is popular all over India. The Folk Hindus call the cow Gou Mata (mother cow) because of its usefulness; the cow is patient, gentle, and beneficial in every respect. Her excreta, called gober, is considered holy and thus plastered thinly on the surface of the house temple and the place where they take meals, to purify the places. Thomas affirms that for all Hindus the cow is goddess: "Whatever the origin of the worship, the cow is at present held to be a sacred animal by the Hindus. She is not only venerated but actually worshipped as a goddess."3

Killing a cow cannot be accepted by any devoted Hindu. The animal is greatly protected. It is considered unethical to use her for ploughing or any work anywhere.

The bull is called nandi and venerated. Idols are carved of wood or stones and kept in temples to worship. This worship, however, is not very common in Bengal.

The monkey god known as Hanuman is commonly venerated in Hinduism. Folk Hindus offer milk, water, and food to the monkeys. To harm or kill them is strictly

${ }^{1}$ Ganga-Yamuna are the Ganges and Yamuna rivers. These are considered holy, and in veneration, sacrifices are offered after ritual baths.

${ }^{2}$ Niharranjan Ray, History of the Bengali People (Calcutta: Orient Longmans, 1994), 425.

${ }^{3}$ Thomas, 85. 
prohibited and any offense to them is punishable. Monkeys are symbols of perfect loyalty, as Thomas points out: "He was the most powerful of the monkey chiefs. Hanuman's loyalty to Rama has become proverbial and he is held up as the symbol of faithful and self-surrender. He is the ideal of perfect servant who finds full realization of manhood, of faithfulness, of obedience, the subordinate whose glory is in his own inferiority."

Snakes are worshipped by the Folk Hindus by offering them milk and food. They have a special day once a year, known as Nag-Panchami, to venerate the cobra, the most poisonous snake. Every year several people die during this festival because of snake bites.

Tigers are venerated and worshiped. In October 1998 many people entered the zoo in Calcutta with garlands to offer flowers to the tigers in their cage and two of them were killed. The people worship tigers out of fear. Crook affirms: "The early Bengalis' fear of the snake and tiger is well known; out of dread for those creatures, worship then developed and is still common today.",

Elephants are quite commonly revered and worshiped. In many places people make small or large elephant idols to keep in their house temples. These are venerated and considered a symbol of protection and faithfulness.

\section{Spirit Worship}

The Folk Hindus worship many kinds of spirits, much like the animists. Two kinds of spirits are worshiped: (1) Nonviolent spirits are those which do no harm; (2) benevolent spirits are those who bring benefits under certain conditions. In order to keep the spirits pleased, certain rites and ceremonies are needed; if these are neglected, curses,

${ }^{1}$ Crook, 80 .

${ }^{2}$ Ibid., 169. 
diseases, and other problems result, thus indicating that the spirits are angry. People believe that the correct form of worship, with the appropriate rites, is needed. Otherwise there will be fatal results in the home, especially on the children. Most often these people expel demons by performing rituals such as blowing musical instruments, like the shankh, ${ }^{1}$ or beating a noisy drum. Such demons or spirits are supposed to be the ancestors. To avoid a curse these people may name their children after their ancestors, believing that their spirits will then do no harm to the children. Ray affirms: "Especially the Hindu theory of rebirth, spiritualism and theories of metaphysics, reverence for ancestors and the offering of oblations to them, and many funeral and pre-nuptial rituals, so much a part of our lives and the lives of many of our neighbors, are derived from those inhabitants."

\section{Ancestor Worship}

Thakur, the grandfather of the family, is highly honored and worshiped. Offerings to him include the best possible food. He is the family god. Therefore, all members of the family touch his feet and pay great respect to him. At his death, special cremation services are held by the local priest.

Thakur Ma, the grandmother, is even more venerable than the grandfather. She is praised with the words Jai Mata Di (praise to the mother). The grandmother and the grandfather are worshiped with the expectation that this will result in blessings to the family.

Human sacrifices were very common earlier, until a century ago. According to Crook,

'Shankh is a large sea shell. It produces sound when blown. This sound is unlike any musical instrument, and it is done to appease gods or goddesses or to drive spirits out.

${ }^{2}$ Ray, 386. 
Human sacrifice is no more common now. Until the beginning of the present century, the custom of offering a first born child to the Ganges was common. Akin to this is the Ganga Jatra, a murder of sick relatives on the banks of the sacred river, of which a case occurred quite recently at Calcutta. At Katwa near Calcutta a leper was burnt alive in 1812; he threw himself into a pit filled with burning coal. He tried to escape but his relatives, [his] mother and his sister, thrust him in again and he was burnt. They believed that by so doing he would gain a pure body in the next birth.'

The Folk Hindus have a set period, the Ganga Sagar Mela, a celebration held once a year where the river Ganges meets the ocean. Two decades ago they offered human sacrifices there. Families offered their children, expecting blessings and prosperity. The mortality rate among children is very high. This happens, Folk Hindus point out, because the spirits are angry with human beings and take revenge on children.

\section{Principal Deities}

Folk Hindus also venerate the traditional Hindu gods. Brahma is considered the creator god of the whole universe. Vishnu is the preserver god. Shiva is the destroyer god. Kalki is considered the last Avatar (incarnation of a god), tomorrow's incarnation. The local Hindus have erected many marble idols in the Birla Temple of Calcutta: One of them is Kalki, a person dressed in white, sitting on a white horse, with a sword in his hand to destroy all the enemies and set up his holy kingdom. The concept is somewhat similar to that found in Rev 13:8. Multitudes pay honor to Kalki without knowing much about the marble idol in the Birla Temple at Calcutta. ${ }^{2}$

The beliefs and practices of Folk Hindus are not always clearly defined. They have a concept of divine supernatural power, and holy places recognized as shrines (than) where the local deities are worshiped.

In some places the "than" is open to the sky or under the shade of a tree, while in others the villagers have built a covering for it. Animals and birds are sacrificed to the "than" whether there is an image of a deity there or not. The

${ }^{1}$ Crook, 169.

${ }^{2}$ M. P. Agarwal, interview by author, Calcutta, 1997. 
villagers make vows in its name and offer it reverential devotion, yet it is significant that it has no place inside the village. Local deities are not known everywhere by the same name or in the same form. ${ }^{1}$

\section{Festivals}

Hindus and Folk Hindus celebrate festivals at the same time but separately. The purposes of these celebrations are (1) to recognize and honor their deities, at least once a year; (2) to meet with friends and relatives and strengthen relationships; (3) to enjoy food and have fun going out or visiting tourist or historical places; (4) to remember and strengthen belief in the particular festival; and (5) to unite and show cooperation with the society and believers of the same faith.

We shall consider some of the festivals and their function in relation to Folk Hindu beliefs and practices.

\section{Durga}

The Durga festival is generally celebrated after the rainy season. Rain is the time of floods and destruction, sickness and death, loneliness and separation, and of much hard labor, planting rice and cultivating vegetables. This festival wipes out all those negative elements. Durga is considered to be a very important goddess, to be worshipped with great honor. "She obtained the name Durga because she slew an Asura (giant) named Durga, the name of the goddess being the feminine form of the demon's name." ${ }^{\text {B }}$ Bettany affirms: "The festival of Durga in Bengal is specially elaborate. Durga herself has ten hands, holding weapons emblematic to her victories."

In some places the festival is called Dashara and is celebrated with great joy once

\footnotetext{
'Ray, 389.

${ }^{2}$ W. J. Wilkins, Hindu Mythology (Calcutta: Rupa and Co., 1973), 296.

${ }^{3}$ G. T. Bettany, Encyclopedia of World Religions (New York: Dorset Press, 1988), s.v. "Deities."
} 
every year. People offer the blood of animals, flowers, fruits, and sweets. Whenever the puja rites are performed, the priest, a Brahmin or Pujari, is called.

In Bengal the worship of this goddess forms the most popular of all the Hindu festivals; it continues for three days, and is the great holiday of the year.

Sacrifice of buffaloes and goats are made to her; feasting, singing, and dancing are continued through the greater part of the night. ${ }^{1}$

\section{Deepavali}

Deepavali is the festival of lights. This comes annually, sixteen days after the Durga festival. All Hindus celebrate it with great rejoicing. Deepavali are small clay pots used for lamps. Now the people have adopted the use of colored electric lights. Traditionalists have several clay pots filled with oil and a wick in each. The lights are on walls, around the houses, on the terraces, and in residential surroundings. It is said that this festival is especially for the goddess of wealth, Lakshmi. She is colorfully decorated and worshiped by all Hindus.

The festival occurs during the harvest time when the farmers praise Lakshmir for blessing their crops. According to Dubois:

This feast appears to be specially dedicated to the fire. But as it is held at a time when most of the cereal crops are ready for harvesting, the cultivators in many places are then in the habit of going together in procession to their fields, and there offering up to their crops prayers and sacrifices of rams or goats, in order, as it were, to give thanks to their crops for having ripened and being fit for the food of man. ${ }^{2}$

The purpose of the festival has been forgotten. It has become an opportunity for entertainment, food, fun, sightseeing, visiting, and much drinking and gambling. All this is done in the name of the goddess.

\footnotetext{
${ }^{1}$ Wilkins, 300.

2J. A. Dubois, Hindu Manners, Customs, and Ceremonies (Delhi: Book Faith India, 1999), 578-579.
} 
Holi

Holi is celebrated annually by all Indian Hindus. About its history, Ray writes:

"It is now established that Holi was initially a rural celebration in the hope and entreaty for a good harvest. Its many features were human sacrifices and erotic song and dance; in time, human sacrifice came to be replaced by animal sacrifice, and the ablation of fire and ghee was included."1

A special puja is observed. All sacrifices and rituals are performed by the pujari (priest). The people enjoy spraying colored liquid or powder on each other. As they do this there is great exchange of happiness and joy among them. The day ends with festivity; men usually gamble and drink.

Lakshmi, the goddess of wealth, is worshipped during the Holi festival by all Hindus. Kanitkar notes that this "is the most important festival for merchants, bankers, and businessmen, because the main religious event is worship of Lakshmi the goddess of wealth in Hindu mythology."2

\section{Rakhi Bandhana}

Rakhi Bandhana is the tying of lucky threads by a sister to her brother on the fullmoon day of July-August. Antoine, de Smet, and Neuner describe this celebration: "Accordingly, in each family, sisters bind brightly colored strings on their brothers' wrists." Being an Indian and living among the Hindus, I have witnessed that as this festival approaches the shops are full of colorfully designed threads for sale. The sisters in Hindu communities buy them and on the marked day, with great preparation, tie these

${ }^{1}$ Ray, 394.

${ }^{2}$ V. P. Kanitkar, Hindu Festivals and Sacraments (New Barnet, UK: By the author, 1984), 6.

${ }^{3}$ Robert Antoine, Richard V. de Smet, and J. Neuner, eds. Religious Hinduism: A Presentation and Appraisal (Mumbai: St. Paul's Society, 1996), 184. 
strings respectfully and lovingly on the wrists of their brothers. The day is spent with festivity, with the men making a commitment to love and respect their sisters, providing them with gifts and assurance.

\section{Krishna Jayanti}

This festival is also called Gokulastami or Jamastamy and is the celebration of Lord Krishna's birthday. In addition, his mischievous childhood and youthful exploits are celebrated and reenacted. Colorfully decorated images of Krishna, his mother Devaki, and other deities are displayed in a specially constructed public place. ${ }^{1}$ Dishes of sweets are offered to the child-god Krishna and later distributed among the people. This ceremony is followed by singing, dancing, and acting out the drama of the child Krishna climbing up on the roof where there is an earthen pot filled with butter. As this pot is brought down or broken, all the household worshipers share the butter and rejoice.

\section{Sarashwati}

Sarashwati, the goddess of wisdom, is also celebrated. In some places, her feast is called Mavaratra, and lasts nine nights. Sarashwati, "the gentle, refined wife of Brahma, seen in her pictures with the Vina [an Indian musical instrument] in her hand and a peacock at her side, is the goddess of speech and learning." She is decorated colorfully with clothes and lights and elaborately worshipped by all, especially by students, who place before her image or picture their offerings of toys, books, rice, flowers, and coconut. The day turns to be a joyous occasion of singing, loud music, and parties. 1976), 9.

'Ibid., 185; see also David R. Kinsley, The Sword and the Flute (Delhi: Vikas,

${ }^{2}$ Antoine, de Smet, and Neuner, 186. 


\section{Vaisakh or Baisakhi}

This festival is agriculture based, celebrated with gusto and gaiety by all Hindus. It falls in March-April, Baisakhi, the first Hindu month of the year. As usual, it is obligatory to bathe in the holy river and follow certain rituals. Wilkins notes that this is the first festival of the year. At this time, cold, miserable days usually give way to warmer ones and fields become beautiful with the swaying of yellow sarson (mustard).' The puja is begun by the youngest girl present by applying the teeka (red mark on forehead) on every one. I have observed that children and youth fly kites the whole day, enjoying the festive mood. The kites are legendary symbols in Hindu mythology.

\section{Ceremonies}

The Folk Hindus, unlike the Hindus, have many ceremonies with daily religious practices that include various local articles. Among these are rice, grass, flowers, bananas, turmeric, betel nut, coconut, vermillion, oil, and cow dung.

Farquhar notes some domestic ceremonies observed by the folk Hindus. These follow the life cycle. One month after a marriage, Garbhana is celebrated to inaugurate the woman's pregnancy. Three months after the marriage comes a ceremony of production, Pumsavana. A hair-parting ceremony (Simantonnayana) is held for the pregnant woman shortly before the birth of her child. When she delivers, Jata-karman, a birth ceremony, is celebrated. Nama Karma is the ceremony of name giving. When the child is carried out to look at the rising sun, Nishkramana is celebrated. Even the first solid food given to a baby is celebrated. Kesanta accompanies the first hair cutting. When a child is first introduced to education or societal duties, Upanayana is celebrated.

'Ibid.; see also V. N. Narayana, "Day of Homage and Hope," Bhavan's Journal, April 16-30, 2001, 23. 
Finally, Vivaha is the ceremony for marriage. ${ }^{\prime}$

Three ceremonies are described in detail. They are the ones carried out at childbirth, marriage, and death.

\section{Childbirth Ceremony}

A mother is considered unclean for ten to fifteen days after childbirth. A pujari is called to write down the birth date, time, place, and the planet or star of the day to decide the fortune or misfortune of the child.

The pujari is called for the Nama-karma (name-giving ceremony) to name the child and perform the ceremony connected to it. This takes place six months after birth. The family, relatives, and friends are called to join in the feast and they rejoice celebrating the ceremony.

Wilkins gives more light on the naming ceremony:

When a boy is six months old, his name is formally given and a festival called Anaprasna or rice-eating is observed. The child, beautifully dressed and decorated with jewels, is brought into the guest chamber and a few grains of cooked rice are put into his mouth. ${ }^{2}$

This is followed by great joy and festivity and social fellowship in honor of the child's name-giving ceremony.

Many rituals are connected with the development and growth of a child until he or she is ready to be married. In most cases Folk Hindus arrange child marriages, depending upon their star, age, and economic condition.

\section{Marriage Ceremony}

The date is fixed by the purohit (priest) according to the suitable star/planet.

When everything is arranged, the purohit makes a special fire in the pandal and makes $146-147$.

'J. N. Farquhar, Primer of Hinduism (London: Christian Literature Society, 1911),

${ }^{2}$ Wilkins, 297. 
the bride and bridegroom sit, surrounded by relatives and guests. Then he calls the ancestors' spirits and gods to bless the couple, and performs the rituals on their behalf. After the rituals are performed the marriage party enjoys singing, dancing, and feasting in the bride's house. Before the bride leaves for her home, she receives gifts from her relatives. A marriage sign of vermillion is put on her forehead on the parting line of the hair and a thali (a gold chain) is placed around her neck. A similar feast is then performed in the bridegroom's house. Additional rituals are performed there. In any case, the marriage ceremonies are considered very important. Still a "brahmin 'purohit' does not usually preside at a sudra marriage" unless the parties are rich or of high position. ${ }^{1}$ Shah highlights the purpose of marriage: "Motherhood is the outstanding aim of the Indian marriage ideal." ${ }^{2}$ This is true with Folk Hindus also.

\section{Funeral Ceremony}

When a Folk Hindu dies, there are fewer ceremonies to perform than when a highclass Hindu dies. As soon as a Folk Hindu dies, the relatives wash the body and have the head shaved by the barber. The body is covered with a white cloth kafan. They may put flowers and burn incense known as agarvati. The body is carried to the samsan (crematory). There are many variations of the funeral ceremony in different places.

Jones affirms that cremation is not the end of the ceremony. "Funeral ceremonies do not terminate with the burning or with the burial of the body in Hinduism." ${ }^{3}$ There are further rituals such as mantras, chanting, and hair-shaving, after which they bathe in a nearby river for purification. After cremation the ashes are collected and respectfully put

'Dubois, 233.

${ }^{2} \mathrm{~K}$. T. Shah, The Splendor That Was India (Bombay: D. B. Taraporevala Sons and Company, 1930), 198.

${ }^{3}$ J. P. Jones, India: Its Life and Thought (New Delhi: Rare Books, 1974), 272. 
into the holy river. A feast is called one month after the death of a person to recall his good deeds, a tribute is paid by the family members. This information comes from conversations with Folk Hindus of Calcutta.

\section{Superstitions}

The traditional society of the Bengali Folk Hindus is permeated by all kinds of superstitions. These are deeply rooted and affect religious beliefs and practices.

Any unusual event, such as the sudden breaking of a branch, is considered a curse. If this happened, the Folk Hindu would discontinue his mission or journey.

If a black cat crosses a road before a person, this may announce an accident or a failure in business. So, the person changes plans and does the thing another day. If you are traveling on a bus or in a hired taxi, the driver would stop the motor and start it again. Sneezing and yawning are also considered to be bad omens.

To protect from an evil eye, a traditional Bengali Folk Hindu applies a black spot on her child when she goes out to the market or puts kajal (a black eye salve in the eye) so that no curse or bad effect of evil eyes would occur. Churrel is the spirit of the pregnant woman who dies before she delivers. To make appeasement Folk Hindus may offer some rituals. In some cases animal sacrifices are needed, affirms Crook, to avoid the evil effect of the spirits. "Blood is naturally closely connected with life. But blood itself is most effectual against demonial influence."1

\section{Astrology}

Astrology plays an important role among the people and "no important event takes place without consulting the village astrologer."' Folk Hindus assume that the heavenly bodies control human life from birth to death. They especially avoid looking at

${ }^{1}$ Crook, 19.

${ }^{2}$ A. P. Berardo, Indian Mind (Mangalore: Codiabail Press, 1960), 120. 
the sun, moon, and stars during eclipses, and they prefer to fast on these days.

\section{Palmistry}

Palmistry is a method of interpreting someone's future by looking at the lines on the palms. Folk Hindus pay a fee to the diviners for this service. Practically everybody is involved. Palm reading is common among those seeking to know what fortune or misfortune they may have, for example, for marriage, business, or education.

\section{Witchcraft}

Sorcerers, charmers, and magicians belong to this category. They have kept the target group in the clutch of their beliefs and practices. To protect from the evil effect of "evil eye," all people, and particularly the Folk Hindus, put a black spot on the forehead of their children.'

\section{Karma}

Whether in the sacred writings (Vedas) or in the minds of rural Folk Hindus, it is accepted that good deeds follow in the next birth, as the Hindus believe. The people believe in "merit transfer," by which "the doer of good becomes good, the doer of evil becomes evil." ${ }^{2}$ So there is no escape from the clutch of karma. Ayoorkyzhiel elaborates on karma: it "is the belief that every man has to experience the fruits (phalam) of his karma (actions), both good and bad." ${ }^{33}$ The following comes from an interview with a Hindu man. A man deceived his neighbor and falsely accused him, and won the case in the court. After a few days his son met an accident and died. All the neighbors started 210.

${ }^{1}$ Denzil Ibbetson, Religious Life of Indian People (Delhi: Amar Prakashan, 1991),

${ }^{2}$ Wendy Doniger O'Flaherty, Karma and Rebirth in Classical Indian Traditions (Delhi: Motilal Banaras, 1983), 3.

${ }^{3}$ A. M. A. Ayrookuzhiel, The Sacred in Popular Hinduism (Madras: Christian Literature Society, 1981), 124. 
saying that the person was a liar, therefore his karma (bad action) resulted in the loss of his son. ${ }^{1}$ Ayrookuzhiel affirms this: "That a man must bear the consequence of his deeds was considered to be an obvious truth." ${ }^{2}$ There are many who believe that karma means what is written in one's fortune and everything happens according to it.

\section{Maya}

Maya is defined as a feeling of illusion and lostness. Johari Harish affirms: "The One is reality. Multiplicity is illusion. Maya is illusion."3 Amaladass points out: "The true nature of maya is indefinable. It is neither real nor unreal." 4 Therefore, it is a false speculation, false knowledge, and a great deception of which the Folk Hindus are ignorant, yet they believe it.

This presentation gives an overview of moon beliefs, observances, and superstitions. Now we will examine what Christianity has done and how the Bengali Folk Hindus have responded to it.

'P. Choudry, interview by author, Calcutta, October 19, 1999.

${ }^{2}$ Ayrookuzhiel, 125.

${ }^{3}$ Johari Harish, Leela: The Game of Self-Knowledge (New York: Coward, McCann \& Geoghegan, 1975), 36.

${ }^{4}$ Anand Amaladass, ed., Christian Contribution to Indian Philosophy (Madras: Christian Literature Society, 1995), 245. 


\section{CHAPTER 3}

\section{CONTRIBUTIONS OF CHRISTIANITY AND THE RESPONSE OF BENGALI FOLK HINDUS}

In this chapter mention is made of a few of the contributions of some Roman Catholics and Protestants (including Seventh-day Adventists) towards the planting of Christianity in Calcutta. The chapter ends with a review of the response of Bengali Folk Hindus to Christianity.

\section{Roman Catholic Church}

The archdiocese of Calcutta covers the greater part of West Bengal. The first missionaries landed here at the end of the sixteenth century at Bandel. The first Roman Catholic chapel is dated 1700 .

On February 17, 1845, the Holy See divided the vicariate of Bengal into the vicariate apostolic of Calcutta and the vicariate apostolic of Chittagong (now in Bangladesh). Calcutta became the archdiocese of Calcutta in 1886. Mission fields were assigned to it, not only in West Bengal, but also in Bihar, Assam, and Orissa. ${ }^{1}$

In every aspect the Roman Catholic Church progressed rapidly. It took into consideration the local culture and the local languages. "It was under the leadership of Fr. Roothan of the Society of Jesus that the Catholic mission saw a new vision by the means

'H. D'Souza, The Directory of the Archdiocese of Calcutta (Calcutta: Catholic Press, 1999), 1. 
of English education." St. Xavier's School at Calcutta was opened in 1837.'

The educational system boosted Catholic growth in Calcutta and West Bengal.

Table 5 shows the institutions and their growth. ${ }^{2}$

The 1998 situation of the Roman Catholic Church is shown in tables 4 through 7.

Table 4 shows the increase of Roman Catholic institutions from 1920 through 1977.

Table 5 depicts the total Catholic presence in the Bengal diocese. Table 6 shows Roman

Catholic health and welfare activities. Table 7 deals with Catholic educational work.

TABLE 4

ROMAN CATHOLIC INSTITUTIONS AND THEIR

GROWTH (1920-1977) IN BENGAL

\begin{tabular}{|c|c|c|c|c|c|c|c|}
\hline$\overline{\overline{\text { Institutions }}}$ & 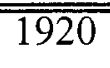 & 1933 &  & $\overline{1948}$ & 1959 & 1969 & 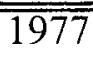 \\
\hline $\begin{array}{l}\text { Primary and } \\
\text { Middle Schools } \\
\text { High Schools }\end{array}$ & $\begin{array}{r}66 \\
7\end{array}$ & 5 & $\begin{array}{r}198 \\
21\end{array}$ & $\begin{array}{r}267 \\
24\end{array}$ & $\begin{array}{r}223 \\
41\end{array}$ & $\begin{array}{r}201 \\
88\end{array}$ & $\begin{array}{r}132 \\
93\end{array}$ \\
\hline Technical Schools & - & - & 9 & 6 & 10 & 20 & 24 \\
\hline Colleges & - & 3 & 5 & 6 & 6 & 4 & 6 \\
\hline Hospitals & 1 & 1 & 1 & 1 & 10 & 10 & 12 \\
\hline Dispensaries & 11 & - & - & 5 & 56 & 48 & 61 \\
\hline $\begin{array}{l}\text { Social Work } \\
\text { Centers } \\
\text { Orphanages }\end{array}$ & $\overline{8}$ & $\overline{10}$ & - & $\overline{13}$ & $\begin{array}{c}6 \\
21\end{array}$ & $\begin{array}{r}8 \\
25\end{array}$ & $\begin{array}{l}24 \\
28\end{array}$ \\
\hline $\begin{array}{l}\text { Homes for the } \\
\text { Aged }\end{array}$ & 2 & 2 & 2 & 1 & 2 & 2 & 5 \\
\hline Leprosaries & - & - & - & - & 1 & - & - \\
\hline $\begin{array}{l}\text { Homes for the } \\
\text { Destitute }\end{array}$ & 1 & 2 & 2 & 2 & 1 & 1 & 8 \\
\hline
\end{tabular}

Source: F. Houtart and G. Lemerimier, Size and Structures of the Catholic Church in India (Louvain-la-Neuve: Université Catholique de Louvain, 1982), 168-185.

'G. Kottunpapallil, History of the Catholic Mission in Central Bengal (18551986) (Shillong: Vendrame Institute, 1988), 18.

${ }^{2}$ F. Houtart and G. Lemerimier, Size and Structures of the Catholic Church in India (Louvain-la-Neuve: Université Catholique de Louvain, 1982), 168-185. 
TABLE 5

ROMAN CATHOLIC PRESENCE IN BENGAL, 1998

\begin{tabular}{|c|c|c|}
\hline Catholic Presence & No. & \\
\hline Diocesan Priests & 89 & \\
\hline Religious Priests & 138 & \\
\hline Brothers & 87 & \\
\hline Sisters & 920 & \\
\hline Seminaries (Minor) & 13 & \\
\hline Seminaries (Major) & 36 & \\
\hline Parishes/Quasi-Parishes & & 52 \\
\hline Pastoral Centers & 7 & \\
\hline
\end{tabular}

Source: F. Houtart and G. Lemerimier, Size and Structures of the Catholic Church in India (Louvain-la-Neuve: Université Catholique de Louvain, 1982), 168-185.

TABLE 6

ROMAN CATHOLIC HEALTH AND WELFARE ACTIVITIES, 1998

\begin{tabular}{lr}
\hline \hline Program & No. \\
\hline Hostels & 29 \\
Orphanages & 7 \\
Dispensaries & 46 \\
Homes for Sick and Disabled & 13 \\
Homes for Aged & 3 \\
Welfare Programs & 16 \\
\hline
\end{tabular}

Source: F. Houtart and G. Lemerimier, Size and Structures of the Catholic Church in India (Louvain-la-Neuve: Université Catholique de Louvain, 1982), 168-185. 
TABLE 7

ROMAN CATHOLIC EDUCATIONAL INSTITUTIONS, 1998

\begin{tabular}{lccccc}
\hline \multicolumn{1}{c}{ Kinds of } & Number of & \multicolumn{2}{c}{ Students } & \multicolumn{2}{c}{ Staff } \\
\multicolumn{1}{c}{ Schools } & Schools & Catholic & Others & Catholic & Others \\
\hline Primary & 64 & 5724 & 32,100 & 368 & 944 \\
Secondary & 49 & 3540 & 26,589 & 386 & 1,188 \\
Higher & 10 & 465 & 2,769 & 41 & 229 \\
Secondary & & & & & \\
Commercial & 5 & 93 & 197 & 13 & 23 \\
Technical & 4 & 113 & 259 & 11 & 35 \\
Colleges & 3 & 455 & 4,257 & 4 & 34 \\
\hline
\end{tabular}

Source: F. Houtart and G. Lemerimier, Size and Structures of the Catholic Church in India (Louvain-la-Neuve: Université Catholique de Louvain, 1982), 168-185.

\section{Protestant Missions}

Contributions of William Carey (1761-1834) and the Baptists

A new era started with the arrival of "the Father of Modern Missions," William

Carey, who reached Calcutta in 1793. Carey's greatest contributions were the translation of the Bible into many languages, including Bengali; opening many schools; and establishing the theological seminary or Bible college in 1813 at Serampore, about $40 \mathrm{~km}$ northwest of Calcutta. Carey was also known for the training of indigenous church planters and evangelists.

Samuel Raj says the following about Carey's great contributions to education:

Carey believed that education could illuminate the individual mind to realize the truth of the gospel. He made elaborate schemes to weed out ignorance and superstition through education. When the doors were open in 1817, Carey started 45 schools within a year, and more than 130 schools were set up by $1828 .{ }^{\prime}$

'Samuel A. Raj, Attempt Great Things (Calcutta: SAILEE, 1993), 79. 
The Baptist Church started with the father of modern mission, William Carey, in 1793. Only a few local Bengalis became Christians to begin with, but today there are eleven churches with over 2,000 members in fourteen Hindi, Bengali, and Englishspeaking groups. The Baptists have three high schools with more than three thousand students. They also operate one medical unit, three social service centers, and one printing press with a monthly magazine called Vision to express the progress and objectives of Christianity. There is one Bible college with more than one hundred students.

Contributions of Alexander Duff (1806-1878)

Protestantism gained momentum with the great vision and contribution of Scottish missionary Alexander Duff. A Presbyterian missionary, he came to India in 1829.

Duff was highly qualified (D.D., LI.D.). He decided to change the method of approaching Hindus. He introduced and promoted higher education. His medium of instruction was English. He taught Bible as a compulsory subject for moral development. The "Bible was the major text book."2 Many wealthy families sent their children to study in Duff's schools and he became very popular and influential. Duff also encouraged women's education and provided a formal education for them. Latourette evaluates: "Duffs greatest contribution was to improve Indian education. More than any other one man he laid the foundation for the use of higher education by Protestants as a means for reaching the youth of India. The results in the permeation of India with Christian ideas were more striking than the direct conversion.",3

\footnotetext{
${ }^{1}$ Sudeep Biswas, senior pastor, Baptist Church, interview by author, November 4 , 2000, Calcutta.

'J. D. Douglas, ed., Who's Who in Christian History (Wheaton, Illinois: Tyndale House, 1992), s.v."Alexander Duff."
}

${ }^{3} \mathrm{~K}$. S. Latourette, A History of the Expansion of Christianity (New York: Paternoster Press, 1971), 6:117. 
Contributions of the Assembly of God Church

This church was founded in Calcutta by Sally Sympson in 1907. Rev. Menote Ketchan started an orphanage for girls in 1926. Daniel Marraco, an able missionary, started a church in a rented building on Park Street in 1946. By then hundreds of people were attending. In an interview R. Maitro, who currently serves this church, noted that Rev. Mark Buntain and his wife Huldah came in 1954. They purchased a large plot of old cemetery by Park Street and by 1981 had constructed a beautiful church, a hospital, a school, a vocational training center, an old people's home, and a huge commercial complex in one campus. Rev. Buntain died in 1989. He was succeeded by his wife and currently by Dr. John Higgins.

The Assemblies of God hold services in eight languages: Hindi, English, Bengali, Oriya, Tamil, Telugu, Malayalam, and Nepalese. There are 4,000 members in Calcutta. Under Calcutta leadership, they have sixty churches in West Bengal, with more than one hundred pastors and evangelists. The denominbation has twenty-nine institutions which are operated in English, Hindi, and Bengali. The Assembly of God Church also has a large hospital, four clinics, one nursing training school, and one training center for nursing administration attached to the hospital.

Maitro stated that the Assembly of God has six social service centers which feed 25,000 people every day. Besides this, they run a vocational school to train the city youth in carpentry, printing, auto mechanics, electronics, and catering. They also have one teacher training program, two orphanages, one old age home, and one printing press in Calcutta. They also provide jobs for the new converts as needed. Besides these, more than one hundred evangelists conduct evangelistic meetings in Calcutta. ${ }^{1}$

'Kalyan Maitro, pastor, Assembly of God Church, interview by author, Calcutta, November 3, 2000. 
Contributions of the Church of North India

This church was established in 1847 by the British government as an Anglican ministry to the military. The first chaplain was a retired pastor, Thomas Fanasaw. The church was not intended to evangelize Indians. Later the church grew through missionaries and schools, medical centers, and social services. Today the Church of North India has thirty churches in and around Calcutta with over 15,000 members. There are thirty institutions, which include schools, orphanages, and social service centers. Bishop College in Calcutta prepares gospel missionaries.'

\section{Seventh-day Adventist Church (1890-2000)}

Clear information on the early years is difficult to find. Early in 1890, S. N. Haskell and P. T. Magan visited Calcutta. Their purpose in visiting India was to "gain information that would enable them to give counsel and advice when active missionary operations should begin ... in that field."2 Later, G. C. Tenney was sent on a fact-finding mission. He arrived in Calcutta on November 3, 1892, from Melbourne, Australia. ${ }^{3}$ In 1893 William Lenker and A. T. Stroup, two colporteurs from America, began selling Adventist books among those who spoke English. ${ }^{4}$

According to W. A. Spicer, "The first settled mission was in the great city of Calcutta. In 1895 D. A. Robinson began evangelistic meetings. An English church was developed." He further noted:

The Seventh-day Adventist Church in Calcutta was established with the hard

\footnotetext{
${ }^{1}$ Victor Yardi,Vicar of the Calcutta Parish of the North India Church, interview by author, Calcutta, November 3, 2000.

${ }^{2}$ J. N. Loughborough, The Great Second Advent Movement: Its Rise and Progress (Washington, D.C.: Review and Herald Publishing Association, 1905), 438-439.

${ }^{3}$ R. M. Masillamony, History of Early Seventh-day Adventist Work in Southern Asia (Palayan Kottai: Tiruelveli Diocesan Press, 1982), 28.

${ }^{4}$ Seventh-day Adventist Encyclopedia (1996), s.v. "India, SDA Work."
} 
work of zealous missionaries. The new converts, too, engaged in assisting the missionaries in the evangelistic meetings. In due course of time they received training. In this period the church flourished. The church members were comprised of foreign nationals, Anglo-Indians, and Hindu Bengalis who were converted. Public preaching, teaching, and home Bible studies were given. A sanitarium in Calcutta, started by Dr. O. G. Place, was another source of bringing souls to the church. ${ }^{1}$

Of D. A. Robinson, L. G. Mookerjee, one of the first converts, wrote:

When D. A. Robinson came to India [1895], arrangements were made, and the Seventh-day Adventist Mission took over B. N. Mitter and family in their work at the orphanage in Calcutta. This orphanage, known as "The Home for Destitute Indian Children," was opened in July 1897 with twenty-nine destitute children at 154 Bow Bazaar Street, Calcutta, in quarters adjoining our first Mission House. ${ }^{2}$

In 1896 Ellery Robinson and his wife arrived in India. The following year he was the only colporteur working in this land. "He concentrated his work in the city of Calcutta."

\section{Georgia Burrus}

The first regular missionary to reach India, appointed by the Seventh-day Adventist Mission Board, was Georgia Burrus, a Bible instructor from California. ${ }^{4}$ Miss Burrus (who later married Luther J. Burgess) ${ }^{5}$ arrived in Calcutta on January 23, 1895. Her loneliness was overcome by the presence of Mr. and Mrs. Masters who were waiting to meet her on the shore. They helped her find lodging. Later, that same year, the Masters returned to Australia due to ill health. ${ }^{6}$

${ }^{1}$ W. A. Spicer, After One Hundred Years (Washington, D.C.: Review and Herald Publishing Association, 1944), 76, 324-325.

${ }^{2}$ L. G. Mookerjee, "A Comprehensive Survey of the Early Work," Eastern Tidings, May 6, 1941, 7.

${ }^{3}$ Spicer, 49.

${ }^{4}$ SDA Encyclopedia (1996), s.v. "India, SDA Work."

${ }^{5}$ A. W. Spalding, Origin and History of Seventh-day Adventists, 4 vols. (Washington, D.C.: Review and Herald Publishing Association, 1962), 2:324.

${ }^{6}$ L. J. Burgess, “The Blessed Pioneer,” Eastern Tidings, May 8, 1941, 2. 
In March 1896 a school for Hindu girls was opened on the first floor of the mission house under the supervision of Georgia Burrus and May Taylor, with a welleducated Bengali woman as a teacher. The school work helped the young women to master the language and provided the opportunity to visit the homes of the students, where they could teach Christianity to the women secluded in the zenanas (women's quarters) of large families. It was while visiting the zenanas in the neighborhood of the school that Georgia Burrus met Nanibala Biswas, who later became the first Seventh-day Adventist convert from Hinduism, and adopted Burrus as her last name, after the one who acquainted her with Christianity. ${ }^{1}$

\section{Church Development}

About the beginning of December of 1896, D. A. Robinson began conducting regular Sunday night meetings in the mission hall on the topic: "The Christianity of Jesus Christ:What It Is and What It Is Not." He also held several temperance meetings. From the beginning, the meetings were intended for the English-speaking Indians rather than for the Europeans, though both groups were present. As the meetings progressed the attendance increased from 300 to 600 . When the mission house was closed for repairs after an earthquake, a theater was secured, and from July through the next winter, the meetings were held there, the audience contributing enough to cover the expenses. ${ }^{2}$

In 1918 W. W. Fletcher described the Calcutta English congregation as "a unique church where all the members took active part in church activities." They assisted the preacher "wholeheartedly" and circulated the Signs of the Times, since there were no colporteurs that year. ${ }^{3}$

${ }^{1}$ SDA Encyclopedia (1996), s.v. "India, SDA Work."

${ }^{2}$ Ibid.

${ }^{3}$ W. W. Fletcher, "Calcutta English Church," Eastern Tidings January 1918, 5. 
The names of pastors and the membership of the English-speaking church in Calcutta are given in table 8. As can be observed, the membership has not grown well. According to H. R. Gomes, the main contributions made by the listed pastors were as caretakers. When some conducted evangelistic meetings, visited people, and gave Bible studies, the membership grew. Gomes recalled the interest of the early missionaries in the school. Later, there was a health food canteen, but this too did not do well. The church also helped the public by social service, but there was no permanent structure to this. ${ }^{1}$

W. G. Jenson, who was the pastor in Calcutta 1971 to 1974, gave several reasons for the decline of membership after the overseas missionaries left. Jenson felt that the spiritual condition of members was weak, partly because they neglected their devotional life. Pride in the heart led to conflict and personal offenses. At the same time, the pastors and elders were not as active in nurturing the congregation. Furthermore, the members had neglected the sharing of the gospel with others. Jenson said that the pastor and church members should be "in one accord." In his opinion, lay training and the involvement of members, including the youth, are vital. The ministry of church and school, supported by medical and welfare ministries, would contribute to the consolidation and growth of the Seventh-day Adventist Church in Calcutta. ${ }^{2}$

\section{Schools}

Adventist schools played a great role in propagating the message. Besides Georgia Burrus, Nanibala Biswas, and L. G. Mookerjee, we find the name of Keroda

${ }^{1}$ H. R. Gomes, interview by author, October 3, 2000, Calcutta.

${ }^{2} \mathrm{~W}$. G. Jenson, electronic communication to the author, October 3, 2000. 
TABLE 8

PASTORS AND CHURCH MEMBERSHIP OF THE SEVENTH-DAY ADVENTIST ENGLISH CHURCH

\begin{tabular}{lll}
\hline \hline Pastors & First Year & Members \\
\hline 1. P. L. Julowitz & 1930 & No records \\
2. G. A. Hamilton & 1932 & are \\
3. H. M. Peak & 1933 & available \\
4. Woodward & 1936 & \\
5. R. L. Kimble & 1939 & \\
6. A. E. Rowson & 1940 & \\
7. J. C. Dean & 1942 & \\
8. H. M. Peak & 1946 & \\
9. C. A. Boykin & 1947 & \\
10. O. W. Lange & 1950 & \\
11. H. T. Burr & 1952 & 104 \\
12. D. K. Down & 1953 & 702 \\
13. R. L. Burns & 1955 & 70 \\
14. Larson & 1956 & 70 \\
15. A. H. Farthing & 1959 & 70 \\
16. P. Cooper & 1960 & 64 \\
17. G. R. Christianson & 1963 & 64 \\
18. P. Cooper & 1966 & 64 \\
19. C. B. Hammond & 1967 & 75 \\
20. G. Jenson & 1971 & 60 \\
21. O. W. Olfert & 1974 & 56 \\
22. L. G. Mookerjee & 1976 & 50 \\
23. S. P. Chand & 1978 & 46 \\
24. C. Marandi & 1982 & 46 \\
25. S. Kisku & 1985 & 46 \\
26. No Pastor & 1988 & 44 \\
27. S. Bairagee & 1991 & 41 \\
28. No Pastor & 1992 & 55 \\
29. S. K. Shaw & 1993 & 54 \\
30. Eric Kujur & 1994 & \\
31. V. Sam & 2000 & \\
\hline Source. H. R. Gomes & & \\
\hline & & \\
\hline & & \\
\hline
\end{tabular}

Source: H. R. Gomes, interview by author, October 3, 2000, Calcutta. 
Bose who was interested in promoting schools. ${ }^{1}$ One English school was opened in 1899. ${ }^{2}$ A girls' schools was opened at the Bengali Headquarters, at No. 6, Dehi Serampore Road, Entally, Calcutta, around 1917. ${ }^{3}$

Schools and zenana work ${ }^{4}$ for Hindu families were the main avenues that brought members to the church. Non-Seventh-day Adventist students and non-Christian teachers were baptized. ${ }^{5}$

\section{Orphanage}

In July 1897, an orphanage, called the "Home for Destitute Indian Children," was opened with about thirty youngsters, mostly boys from a Hindu background. ${ }^{6}$ A school for them was started in 1917. Because of lack of vision and support the orphanage closed.

\section{Publishing Work}

Seventh-day Adventists began publishing work in Calcutta in 1896. It functioned under the name "International Tract Society." Among the first tracts published in 1896 were: "Can All Be Saved?" and "The Second Coming of Christ," written by E. G. White and translated to Bengali by A. C. Mookerjee. ${ }^{7}$ Later on the publishing work moved to Karmatar in Bihar.

${ }^{1}$ SDA Encyclopedia (1996), s.v. "India, SDA Work."

${ }^{2}$ Mariam Belchambers, "Growing Up with the Work," Eastern Tidings, May 8, $1941,14$.

${ }^{3}$ L. J. Burgess, "Bengali Headquarters," Eastern Tidings, August 1916, 7.

${ }^{4}$ Richard W. Schwarz and Floyd Greenleaf, Light Bearers: A History of the SDA Church (Boise, Idaho: Pacific Press, 2000), 223.

${ }^{5}$ L. J. Burgess, “Bengal,” Eastern Tidings, May 1916, 6.

${ }^{6}$ L. J. Burgess, "Calcutta," Eastern Tidings, May 15, 1917, 2.

${ }^{7}$ SDA Encyclopedia (1996), s.v. "India, SDA Work." 
The SDA Church in Calcutta Today

The Seventh-day Adventist Church at 36 Park Street is well located in the city of Calcutta. The church and its school are built on nearly an acre of land. The beautiful church has a capacity for one hundred. The school has two classrooms and offices for the principal. There are apartments for the pastor and the principal of the school, as well as guest rooms.

In 2001 there were nearly 100 church members, including the English speakers and the Bengali speakers. The school has one thousand students, of whom only three are Adventists. One half of the teachers are not Adventists.

Other SDA churches and institutions in the Calcutta area are listed in table 9. The total membership is 224 . For a city of nearly 15 million, the Adventist membership is pitifully small.

TABLE 9

SDA INSTITUTIONS IN THE CALCUTTA AREA

\begin{tabular}{llc}
\hline \hline Institution & Location & Membership \\
\hline SDA Church (Bengali) & Ramachandrapur & 40 \\
SDA Church (Bengali) & Dum Dum Airport & 31 \\
SDA Company (Bengali) & Shyambazar & 7 \\
Springs of Life Orphanage & Sonarpure & 41 \\
Springs of Life Bible Seminary & Sonarpure & 10 \\
SDA Company (Bengali) & Baroipur & 95 \\
\hline
\end{tabular}

SDA Work in Arambagh

Arambagh is situated $90 \mathrm{~km}$ from Calcutta. Bonamalic Bowmick, a truth seeker and Protestant minister, invited some elders from the SDA Church in Calcutta, but no one 
responded. In 1995 he contacted me. I visited the field with A. B. Roy and A. J. Singh in 1996 and conducted a spiritual meeting at which 54 people decided to accept the Bible truth and Jesus as their personal Savior. John Malick and Jimmy Ayayo (a Kenyan student at Spicer Memorial College) continued Bible study. In January 1999, 129 persons were baptized by Pastor Victor Sam, who was sent by the Southern Asia Division. Sam trained potential leaders with the twenty-seven fundamental beliefs of Seventh-day Adventists in three weeks. Through the work of these laymen and the blessing of God, more than six thousand made their decision in the districts of Hughlee, Milnapur, Burdwan, Bankura, and 24 Pargana South. Pastor Sam told me that he planned to reach a total of 100,000 persons with the gospel message.

Vikash Pann, who comes from a Folk Hindu background, told how he had first been converted from Hinduism to the Greek Orthodox Church in 1985. Some time later, not understanding the Sabbath doctrine, he questioned Banamalick and was led to meet with the Adventists. After hearing a health talk, he decided to quit smoking. Today he pastors more than six thousand Adventists in five districts in and around Arambagh.

Many lay members are involved in training and preaching the gospel to others. The follow-up programs are house-to-house visitation, prayer, Bible study, and Sabbath worship. There are 41 lay members who are full-time volunteers. ${ }^{1}$ The great needs are church buildings, schools, clinics, a cemetery, and mission headquarters in Arambagh.

\section{Response of the Bengali Folk Hindus}

In Calcutta, Christianity has always been considered a foreign religion, because those who brought it were foreigners and introduced it as part of a foreign culture. Christianity in India has always been dressed in a foreign style, with church buildings, music, and worship styles being Western. Furthermore, in comparison with Islam,

${ }^{1}$ Victor Sam and Vikash Pann, interview by author, November 5, 2000, Calcutta. 
Buddhism, Hinduism, Jainism, and other religions, Christianity is considered a latecomer.

On the other hand, there is a limited positive response. For instance, among the SDA Church members, the ones from Bengali Folk Hindu extraction outnumber all other members. Many of them send their children to Christian schools; others would like to. At the same time, as more nationals accept Christianity and worship forms change, Christianity looks less and less foreign.

\section{Resistance}

A number of Hindu leaders have wrestled during the last two centuries with the challenge Christianity and Western culture pose to Hinduism. Some have recognized the great value of education, as imported to India by Duff and other Christian missionaries.' Efforts have been made to make education more available to people in India without some of the Western characteristics considered unacceptable or unnecessary. Rabindranath Tagore and Swami Vivekananda represent this approach. ${ }^{2}$

At least two movements arose in the nineteenth century to combat Christianity by advocating education for the masses ("Brahma Samaj," 1870) and equal access to education for men and women ("Arya Samaj," 1884). ${ }^{3}$ These movements have become the watch tower of Hinduism against Christianity's propagation.

Hindus are concerned with several aspects of Christianity. They resent the persistent criticism of idolatry, spirit worship, nature worship, animal veneration, ancestor worship, astrology, palmistry, and superstitions. They also resist baptism as the

'John Mckenzie, ed., The Christian Task in India (London: Macmillan, 1929; reprint, Calcutta: Punthi Pustak, 1994), 241-242.

${ }^{2}$ William Radice, ed., Swami Vivekananda and the Modernization of Hinduism (New Delhi: Oxford University Press, 1998), 194.

${ }^{3}$ Ibid., 201. 
means to become a church member. Hindus feel strongly about the eating of beef by Christians. The simplicity of Christian worship, as compared with the elaborate ceremonies and festivities of Hinduism, is objectionable. Furthermore, Hindus think that Christianity is an elite religion, with high standards. Converts to Christianity are at times ostracized by family and friends. Many organized groups of people object to the propagation of gospel and conversion of people to Christianity.

\section{Receptivity}

As observed by the researcher, Folk Hindus find some elements of Christianity attractive. They have identified Christianity as a religion of the "level eye," where all are considered equal in society (Rom 12:10). They also have discovered that it is a religion of high morals, which are taught and practiced through church and educational systems (Phil 4:8). Christianity is a religion of acceptance and recognition (John 4:4), where church membership provides identity of belonging (Isa 49:16).

Folk Hindus find that the Christian religion encourages the aspiration of social and spiritual betterment through fellowship (Heb 10:25), with its planned worship programs that put down the caste barrier (Acts 18:6, Eph 2:19). Christianity emphasizes and practices a healthy lifestyle, based on biblical principles (Dan 1:8; Prov 20:1; 1 Cor 6:19). God's love revealed in the Bible and expressed on the cross and the divinity reflected in humanity are established on the power of Jesus, not of the evil spirits (John 1:12; Col 1:13). The only authority is the Holy Bible as the word of God (Heb 4:12), revealed by the power of God (Luke 9:43). This power encounters evil spirits through prayers and the Holy Spirit (Mark 16:17).

The Folk Hindus of Arambagh admit that Christianity has the highest number of social services for calamities and natural disasters (Isa 61:1-2; 58:6-7). It is service oriented, based on "serve with love" (1 John 4:12). It is "mission" oriented, based on Jesus' compassion and commission to "Go" (Matt 28:19-20). 
This chapter has traced the missionary work of Christian churches in the Calcutta area. Special emphasis has been placed on the work of the Seventh-day Adventist Church. The response of the Folk Hindus, with its resistance as well as receptivity, has been pointed out. Chapter 4 analyzes the barriers and bridges for current work with these people. 


\section{CHAPTER 4}

\section{BARRIERS AND BRIDGES TO EVANGELISM OF FOLK HINDUS}

Folk Hindus not only live in Calcutta but also in other places in India. There have been no initiatives to promote this group culturally. This could be partially due to social and ideological barriers. These are issues implanted in the people that are hard to root out. A brief review of these barriers is needed.

\section{Barriers}

\section{Concept of Many Ways}

There has been much dialogue with Folk Hindus. Most of them agree that Christ is a right way. Yet they do not accept Christ. Because of cultural reasons they say: "Well, there are many ways" to go to heaven. ${ }^{1}$ This sentiment is true of all Hindus.

\section{Caste System}

The caste system has been a barrier to these people in accepting Bible teachings. Caste is deeply rooted and one cannot feel that he would be acceptable without it. It is like a frog in a well that sees only the wall inside the well. The people's vision is distorted. They need the experience of the "Light of the world" to enlighten them.

\section{Family Bonds}

Family bonds hold Folk Hindus tight in their traditions. In making decisions, one

${ }^{1}$ R. Singh, a Folk Hindu, interview by author, September 19, 1999, Calcutta. 
person usually leads the whole family. Or, if the family is well united, they have a family committee for the good functioning and discipline of the family. "In Indian social evolution the family has always meant the joint family made up of many generations of collateral relatives living under one roof and sharing a common heritage."'

\section{Inferiority of Women}

The inferiority of women is one of the biggest issues. Culturally, the girl child is treated as inferior to the boy in all aspects. Tara Ali Baig affirms that traditionally it was acceptable "to murder an unwanted daughter, to burn a widow alive, to push a child into the river among crocodiles or sharks.... Burning of widows alive was the worst problem."2 From her birth to womanhood, at her marriage, and when she becomes a widow, the woman is perceived as inferior to the man. Baig states that all the people of India have the right to "equality" according to Article 14 of the Indian Constitution, yet this equality is often not taken into account. ${ }^{3}$

\section{Lifestyle}

Folk Hindus are filled with an inferiority complex by the high caste, who often consider themselves better and more clever than others. Some lifestyle habits have diminished their alertness. Some of the traditional lifestyle habits cause them to suffer, such as pan (betel nut), kainee (chewing tobacco), and drinking. Gambling at festivities and in leisure time is very common. Time, money, and lives are threatened because of such habits. On the other hand, traditionally, their lifestyle is considered a matter of pride and prestige.

\footnotetext{
${ }^{1}$ C. P. Aiyar, The Cultural Heritage of India (Calcutta: Ramakrishna Mission Institute of Culture, 1982), 2:537.

${ }^{2}$ Tara Ali Baig, India's Woman Power (New Delhi: S. Chand, 1976), 17.

${ }^{3}$ Tbid.
} 
Illiteracy and Ignorance

Illiteracy and ignorance prevent these people from envisioning improvements of any aspect of their lives, whether mental, physical, spiritual, social, or economical. The government has been trying to help, but Christianity with an educational mission is the best solution to enlighten the people.

\section{Poverty}

Poverty is a major handicap. Poverty has caused the people to be deprived, to suffer physically, and to worry emotionally. They are under the slavery of poverty and ignore the Giver and the Sustainer of mankind. On the other hand, poverty is often an indicator of receptivity. Jesus directed people to "seek God first" (Matt 6:33) and He will supply all things according to His grace (Phil 4:19). Millard J. Erickson warns us that "the poor and the rich are equal before God and that the righteous poor are superior to the ungodly rich."

\section{Many Gods}

The many-gods concept has deprived Folk Hindus of the real and true God of gods and Lord of lords. Hindus accept a multiplicity of gods: "There are the many small gram devis (village goddesses) found in most Indian villages. Here the goddess is mother of her people, protecting India's vulnerable villages from enemies and natural disasters." Many gods and goddesses, along with nature and ancestral spirit worship, have blinded them, and thus they are unable to cross the unseen bridge to the kingdom of God.

\footnotetext{
${ }^{1}$ Millard J. Erickson, Christian Theology (Grand Rapids: Baker Book House, 1998), 551.

${ }^{2}$ James J. Preston, Cult of the Goddess (New Delhi: Vikas Publishing House, 1980), 10 .
} 


\section{Evil Spirits}

Evil spirits threaten the lives of Folk Hindus in many ways. To appease the spirits they must perform rituals and sacrifices. They fear that the spirit, if not worshiped, will curse the family and cause the failure of crops and business. To counter this fear, Ponraj points out that "evangelism is always effective when the gospel is proclaimed in the power of the Holy Spirit."

\section{Superstition}

Superstition plays a great role in the lives of the target people. For some--the charmers, sorcerers, magicians, witches, and diviners--this is their occupation. For the rest, superstitions are common in their day-to-day lives. Mattan and Kim point out: "Popular religion is the religion of the ignorant people, who are incapable of having mature adult faith and are moved by sentiments and superstitions." ${ }^{2}$ Amaladoss notes that "people do not normally dare to approach the ultimate directly. But they multiply mediators divine as well as human." ${ }^{3}$ To overcome this barrier we need to provide a better way: "Jesus, the way the truth, and the life" (John 14:6). Jesus defeated Satan by the power of the word of God (Matt 4; Luke 4).

\section{Religious Differences}

While there are similarities between Bengali Folk Hinduism, as seen in table 10, the dissimilarities listed in table 11 appear to these people as greater than the similarities.

Even beyond doctrinal differences, Christianity is considered a foreign religion.

'S. Devasagayam Ponraj, An Introduction to Missionary Anthropology (Madras: Mission Educational Books, 1993), 138.

${ }^{2}$ Joseph Mattan and Sebastian Kim, eds., Mission Trends Today (Mumbai: St. Paul Press, 1997), 121.

${ }^{3}$ Michael Amaladoss, Beyond Inculturation: Can the Many be One? (Delhi: Vidyajyoti Education and Welfare Society/ISPCK, 1998), 116. 
To be implanted into their culture, Christianity must take a native style, suitable and acceptable to them.

TABLE 10

SIMILARITIES BETWEEN BENGALI FOLK HINDUISM AND CHRISTIANITY

Bengali Folk Hinduism

Christianity

1. Belief in one unknown super power

1. Belief in one true God-Creator

2. Belief in malevolent and violent spirits

2. Belief in angels and evil spirits

3. Gods are appeased with sacrifices

3. God is honored with sacrifices

4. Celebration of a holy day-Thursday

4. Celebration of a holy day--Saturday

5. Belief in life after death (immediate)

5. Belief in life after death at resurrection

6. Belief in sacred writings

6. Belief in the holy Scriptures

7. Belief in salvation-Nirvana

7. Belief in Jesus Christ for salvation

\section{Bridges}

A missionary must be well informed to understand the cultural situation of untouchability, as did Jesus with a Samaritan woman. The "living water" must be given in a Bengali glass, the "bread of life" must be served in a Bengali dish.

Evangelism requires a thorough survey and good planning. No one catches a fish out of the water. One must come to the shore, get into the water wading or by boat, and use a fishing line or cast a net to catch fish. So it is with evangelism. One must come to the people, be with them, learn their language, and adapt to their culture, sit and eat and live with them. Once they feel accepted they will accept the truth brought to them.

The recognition of these factors that hinder or advance receptivity of the gospel 
among Folk Hindus of Calcutta forms the basis for an evangelistic strategy. Chapter 5 presents a strategy designed specifically for these people.

TABLE 11

\section{DISSIMILARITIES BETWEEN BENGALI FOLK HINDUS AND CHRISTIANS}

\begin{tabular}{c}
\hline Bengali Folk Hindus \\
\hline $\begin{array}{c}\text { 1. Believe and worship super power } \\
\text { with great fear. }\end{array}$
\end{tabular}

2. There are many gods.

3. There are many ways to salvation.

4. There is appeasement with fear.

5. There is a blood sacrifice.

6. They believe in sorcery, divination, magic, witchcraft, etc.

7. They have sacred objects and idols.

8. They believe in atman (soul).

9. They believe in life immediately after death.

10. They believe in salvation by works.

11. They have no sacred book.

\section{Christians}

1. Believe and worship one super power with honest love.

2. There is one God.

3. There is one way-Jesus.

4. There is worship with honor and love.

5. There was a blood sacrifice.

6. They condemn sorcery, magic, divination, witchcraft, etc.

7. They condemn idols and sacred objects.

8. They deny it.

9. They believe in life after death at the final resurrection.

10. They believe in salvation by faith in Jesus.

11. They have the sacred Bible. 
Information presented in chapters 2 through 4 describes the Folk Hindu of Calcutta. This people has definite social and physical needs. They are marginalized by the Hindu society in which they live. They are also somewhat more open to the gospel than the caste Hindus of the same area. Chapter 5 presents an evangelistic approach designed with this people specifically in mind. 


\section{CHAPTER 5}

\section{STRATEGY FOR EVANGELISM}

Good evangelism requires vision of committed leaders and full cooperation of all church workers associated with them. I have been in Calcutta for the last seven years (1994-2000) and served as Calcutta church pastor for four years, and as director of the metro evangelistic region for three years. I was a failure and was discouraged. A number of factors affected my ministry. I visited all over Calcutta and attended other churches' meetings. I was involved in four Seventh-day Adventist evangelistic meetings. I have experienced a number of things. I would like to refer to those elements that sharpened and broadened my vision.

Let us first consider the reasons for the failure of recent evangelism in Calcutta: I was not well acquainted with the culture of the people. I formed committees and involved the church, yet failed to get their total cooperation. There was insufficient preparation for the evangelistic meetings. Several difficulties arose: (1) The speakers arranged for the meetings did not come; (2) the members always considered that evangelism should be entrusted to an evangelist; (3) the preparation of lay members to actively participate in evangelism was not our prime concern; and (4) the target field survey was not adequate. Because of these factors, there was a lack of receptivity among the target group. The felt needs of the target group were not met.

In the previous chapters I have presented an overall view of the Bengali Folk Hindus and their attitude towards Christianity. In this chapter, a workable and wellplanned strategy is suggested to reach the target people successfully. There are three 
parts in this chapter: (1) preevangelistic approaches, (2) tapping of the resources to meet their felt needs, and (3) building bridges to meet their felt needs through social, medical, educational, and religious contacts.

\section{Preevangelism Preparation}

As part of the preparation for evangelism, several activities must take place, some of them concurrently. This section describes the formation of the necessary committees, the orientation and training of the team, revival meetings in the church, and a survey of the target people.

\section{Committees}

Upon the approval of the evangelistic program by the local conference, it is appropriate to call for an important meeting to form the following committees of workers from the local conference and lay members, with specific responsibilities cited.

1. The Office Committee will include all leaders of the subcommittees and discuss the functioning, problems, or needs of each individual committee. It will meet as required. From time to time, the leaders of the individual committees will keep in touch with the chairman of the Office Committee. This committee is also to provide progress reports.

2. The Security Committee will function for the peace and order of the public who would come to the evangelistic meetings.

3. The Program Committee will decide on the program in consultation with the Office Committee, and inform the participants about their decisions. They will also be responsible for the service order.

4. The Music Committee is responsible for all the music presented and all the musical instruments used during the meetings.

5. The Usher Committee oversees the work of the ushers. These are assigned to 
escort the people in and out, as needed. They are responsible for distributing the invitation cards, hand bills, programs, as well as tracts and literature.

6. The Reception Committee has the responsibility of welcoming visitors and regular members, registering the newcomers, and keeping record of attendance.

7. The Advertisement Committee is assigned to put the information in attractive and interesting handbills, news media, and banners announcing the meetings.

8. The Audiovisual Committee, in consultation with the Program Committee, will prepare and display the visual aids required for the evangelistic meeting.

It is advisable to have all the committee leaders to meet every day during the evangelistic campaign to exchange reports with each other. Organizing and orienting the team is vital for the outreach program. According to Hillock,

To achieve teamwork the people involved must see each other on a face-to-face basis. Whether or not a person throws himself into the job depends in part on the way he feels about the supervision, the others, or the task itself. But to gain an adequate feel for the people, the job requires that the team understand its mission as well as the attitude of the other people involved.'

Orientation and Training of the Team

An essential part of preevangelism is to provide orientation and training of the team. This will include spiritual as well as technical preparation.

Each team member must know that the work of evangelism is a sacred work and that it must be anointed with sacred fire from the holy altar of our heavenly Father. The consecrated and devoted prayer life of Jesus was a reason for His success in ministry (Luke 6:12; Matt 5:44; 14:23).

Each person of the team must be a prayer warrior. All participants must learn the

${ }^{1}$ W. M. Hillock, Involved (Nashville, Tennessee: Southern Publishing Association, 1977), 103. 
art of praying. E. G. White wrote that "prayer is the breath of the soul." Praying is the vital source of power to do evangelism. Many great works are accomplished only through earnest prayers. Prayer is the "key in the hand of faith to unlock heaven's storehouse, where are treasured the boundless resources of omnipotence."2 Sam Jebadurai says: "Prayer reminds us of our constant need for God and reassures us of His presence with us. Prayer is a part of God's plan for our growth and for his program in the world." 3

Ralph Mahoney, the founder and director of World MAP, wrote: "It is important for us to know that our prayers are used by God in a very special way to break the powers of darkness."4 The target group must be the special concern of all prayers.

In the beginning the team must learn how to submit, to be humble, to fast, to pray, and to put on the whole armor of God to face the forthcoming spiritual battle. The orientation must also include a review of the Bible principles connected with the commission of Jesus, "Go and teach" (Matt 28:19-20).

In the technical area, all participants should be introduced to the evangelistic approaches that will be used. In some cases, they will need to spend time learning ways to implement these new approaches.

\section{Revival Meetings}

Revival meetings for the whole church, including three days of fasting and praying, must be conducted by experienced pastors or a suitable conference leader. These

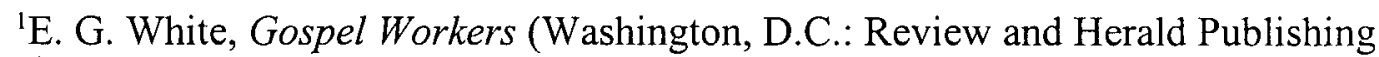
Association, 1948), 254.

${ }^{2}$ E. G. White, Steps to Christ (Washington, D.C.: Review and Herald Publishing Association, 1981), 94-95.

${ }^{3}$ Sam Jebadurai, “Prayer,” Jesus Redeems, July 1997, 23. 163.

${ }^{4}$ Ralph Mahoney, The Shepherd's Staff (Madras: India Bible Literature, 1993), 
meetings will revive the church and motivate all to pray continuously for the forthcoming evangelistic meetings and the target group.

\section{Survey of the Target People}

Such a survey will help to understand the target group: their culture, resistance, and/or receptivity to Christianity. Much has been discussed already in chapters 2, 3, and 4 about the Folk Hindus of Calcutta. This information will constitute the survey for this strategy. Similar information should be gathered for any other target group.

\section{Tapping Resources to Meet Felt Needs}

It is important to tap available resources to help meet felt needs. Many people are exploited. Their suffering may be financial, medical, social, and/or spiritual. While $\mathrm{He}$ was on earth, Jesus met the felt needs of people. Ellen White wrote: "Christ's method alone will give true success in reaching the people. The Saviour mingled with men as one who desired their good. He showed His sympathy for them, ministered to their needs, and won their confidence. Then He bade them, 'Follow Me'."'

\section{Nongovernmental Organizations}

A number of nongovernmental organizations (NGOs) provide for needs of people. Some of these NGOs are sponsored by private Christian organizations. Some of the sponsoring organizations are not Christian. Among the most important working in Calcutta are the Christian Association for South Asia, the Adventist Development and Relief Agency, and the Indian Medical, Educational, and Welfare Service.

\section{Governmental Organizations}

There are also governmental organizations that provide relief and benefits to people at various levels. The "Indira Awas Yojna" provides small but good houses for

'White, Gospel Workers, 363. 
needy people who do not have shelter. Land to cultivate is provided to the landless, and in some places land to construct houses is made available. "Angan Bari" provides free education, with one meal per day, to all elementary school children. They also provide writing paper. A proper contact must be made with the government when help from any of these entities is sought for the target group.

The government also provides free education to all the children up to age fourteen. It helps low-caste students with full scholarships until they complete their high school. Scholarships are provided to colleges also.

Government programs also provide training for youth who cannot go for further study after high school. For instance, they offer training in teaching, nursing, typing, tailoring, gardening, beekeeping, poultry, carpentry, mechanics, or smith work.

Tapping available resources will help to satisfy the felt needs of the target group. The resources thus obtained may also facilitate several aspects of the preevangelistic work for the target group.

In some cases the space for activities is provided. These could be open spaces under trees, in certain streets, old government houses, halls, or rooms.

Sometimes other facilities or resources are provided, such as furniture, water, electricity, or medical aid. Obtaining these depends upon how and when government officials are approached. The officials must be convinced that what is being planned will benefit the public without producing negative political side effects.

The government supplies expertise to develop certain vocational courses, such as training for cottage industries. These experts help in guiding people in a particular vocational course.

For some of the projects the government loans money for buying equipment, vehicles, machines, pumps, or sewing machines to run a small cottage industry. Government projects and programs are intended to benefit the group or individual who 
requests them. These programs provide for the operation of a "cooperative society" to do farming, set up a joint venture business, or run a small cottage industry.

All resources will help the target group to meet their temporal needs. This will strengthen their economic standard. They will have more confidence in the evangelists as social contacts are built with them through these means. These contacts will open the doors to learning their culture and language, and thus increase mutual trust. They will invite the evangelists to be with them. They will better understand the message that we will share with them later. Making these social contacts strong will help to make preevangelism a success.

\section{Evangelistic Approaches}

The evangelistic approaches include social, medical, educational, and religious contacts. These will help to build bridges with the Folk Hindus and prepare them to listen to the gospel message.

\section{Social Contacts}

Previously I mentioned the experience of conducting evangelistic meetings at Sasaram, in Bihar. How we made a social contact is worth noting. At first we sent a team to find out whether the people were receptive or not. When we found out that this group was receptive, we selected two of them to participate in an orientation and help us as forerunners in the villages. Since these people stayed with us and ate with us during the orientation, they developed confidence in us and understood us better.

\section{Cultural Adaptation}

When we approached their village they were happy to receive us. We talked to them and they were very hospitable by sharing water, sweets, and food with us. Their culture was different, yet we did not let them feel odd. We accepted their culture and stayed with them, slowly learning their behavior, culture, and language. As we adapted 
to their culture, they started sitting close to us. They sent their children to help provide for our needs, such as toilet facilities, drinking water, and snacks. We praised God that they were also God's children. This was the first bridge we built between us and them.

They started building the next bridge as they observed our behavior, talk, habits, prayers, Bible reading, and singing. They were attracted to our lifestyle and started changing their lifestyle. This was a quicker way to reach the unreached. We loved them and appreciated what they did for us. J. Oswald Sanders affirms, as he comments on the life of Jesus: "He commended people rather than condemned them. Honest commendation is one of the quickest ways to the human heart."1

In John 4 we find the story of the Samaritan woman whom Jesus interviewed. Sanders affirms that Jesus went out of His way, and crossed the cultural barrier. No decent man was to talk to a woman at the well when no one was there, but Jesus did. Instead of scolding or reproaching her, He asked for a favor. Here He again crossed a barrier. Jesus crossed the sex barrier, the racial barrier, the religious barrier, and the time barrier to satisfy her spiritual felt need and she said to Him, "I know the Messiah is coming" (vs. 25). Jesus said to her, "I who speak to you am He" (vs. 26). Says Sanders: "The ultimate objective of all evangelism had been reached."

At times it may be difficult to approach people who are ignorant, illiterate, and even hostile. Regarding these, Sanders notes: "It need hardly be said that we should approach these people in a spirit of genuine love and not of hostility."

I would like to suggest some valid points that would help establish a relationship at the first social contact, as we adapt to their culture and lifestyle:

${ }^{1} \mathrm{~J}$. Oswald Sanders, Effective Evangelism: The Divine Art of Soul Winning (Bombay: STL Books, 1982), 76.

${ }^{2}$ Ibid., 78.

${ }^{3}$ Ibid., 81. 
1. Be genuine and open, friendly with a smile.

2. Be honest, sincere, and approachable.

3. Trigger thinking by asking a few questions.

4. Listen more than you talk.

5. Never criticize or express doubt.

6. Appreciate their presentation, gesture, or kindness.

\section{Clubs}

Today we find clubs (mandals) in every corner, organized to meet the needs of youth. These mandals unify the youth and place them in activities--games, social work, night classes, literacy, and meetings for planning corporate functions for the maintenance and development of local youth. They are financed by voluntary donations, mostly by collections from passing vehicles or people. They have their own discipline, leaders, and committees.

If rightly approached, these community Hindu youth will be of great help in organizing social welfare, laid as groundwork for evangelism, and will thus strengthen our social contacts. These youth, properly motivated, can be of great help in organizing night schools for children, adult literacy classes, vocational training, and other welfare activities.

In October 1997 I was making social contacts to approach people and did not care much for these mandals. These youth found out that I had been negotiating to conduct religious meetings. Immediately they instigated the villagers to violently oppose us, and they did not allow us to conduct any meetings. Until now we have not been able to enter that target people, even though there are some who are interested in hearing and even accepting the gospel message. Mandals are helpful, if rightly approached, to enter any area in Calcutta and West Bengal. 


\section{Dialogue}

Another method of social contact is dialogue, which creates interest, ideas, openness, acceptable friendship, and vision. It helps to bridge two parties, groups, individuals, and cultures. True dialogue is an effective and sensitive way to meet the needs of others, to build up relationships. However, we must use this method properly. In dialogue we share our common understanding of humanity. It is one of the best gifts that God has bestowed on humanity.

Christ's method of dialogue is a model for us. Several dialogues are recorded in the Gospels: with the Samaritan woman (John 4); with Nicodemus (John 3); with Zacchaeus (Luke 19); with the rich young ruler (Mark 10:17-23); with the thief on the cross (Luke 23:43); and with Mary, Martha, and Lazarus (Luke 10:38-41).

\section{Community Service}

Community service is another way to establish social contacts and build bridges that will help establish a strong relationship. The community service should be designed to meet the felt needs. In my field survey trip I came across a village where the people were interested in accepting the gospel. Ninety percent of the villagers at Falta (near Calcutta) are Folk Hindus. Their needs are schools, a dispensary, drainage, paths, bridges, and toilets. It was heartrending just to pass by that village. The people spread human excreta everywhere: by the side of the path and near their houses. I tried to tell them about health and sanitation, but it was not beneficial. They could not grasp what I was trying to tell them. They still have not built even one toilet. I am concerned for them. I felt that before I could preach the gospel I should try to change their lifestyle by giving them an understanding of a clean, healthy life. But I failed, because they needed a demonstration. I only visited them; I needed to have stayed longer to find resources and to help them build toilets, a dispensary, and a school. I have full confidence that many would have been drawn to the gospel message. 
Medical Contacts

Today the population is growing everywhere, including in the target group. The people are facing sickness of all kinds--jaundice, cholera, typhoid, malaria, diarrhea, scabies, tuberculosis, and cancer. Since these diseases are mostly the outcome of their lifestyle, it is fitting to discuss why these problems exist and how they can be prevented.

The Lord Jesus came to this earth to meet human needs. He "took our infirmities, and bore our sickness" (Matt 8:17). Ellen White says: "He came to give them health and peace and perfection of character." Further, she states: "Varied were the circumstances and needs of those who besought His aid, and none who came to Him went away unhelped. From Him flowed a stream of healing, and in body and mind and soul men were made whole. The Savior's work was not restricted to any time or place."2

Through medical contact, divine wisdom wants us to attempt reaching the unreached. Ministry through medical means brings comfort, healing to the body and satisfaction to the soul. Medical ministry is highly affirmed by Ellen White:

Whether in foreign missions or in the home field, all missionaries, both men and women, will gain much more ready access to the people, and will find their usefulness greatly increased, if they are able to minister to the sick. Women who go as missionaries to heathen lands may thus find opportunity for giving the gospel to the women of these lands, when every other door of access is closed. All gospel workers should know how to give the simple treatments that do so much to relieve pain and remove disease. ${ }^{3}$

\section{Health Awareness}

A health awareness program, whether formal or informal, is one of the best ways to enlighten the minds of the people to the benefits of a healthy lifestyle. This can be done by a friendly talk, by open dialogue, by showing a chart or picture, or by presenting

\footnotetext{
${ }^{1}$ Ellen G. White, Better Living for Your Home (Altamont, Tennessee: Harvestime Books, 1988), 6.

${ }^{2}$ Ibid., 6 .

${ }^{3}$ Ibid., 105.
} 
health rules and health-related pictures and films.

The most successful health orientation that I have been using is the remarkable NEWSTART banners program. There are eight banners, and each has one letter. For example, $\mathrm{N}$ stands for nutrition (which is translated in Hindi and Bengali). Beside the letters there is a picture that depicts various fruits, vegetables, and foods that anyone, even the illiterate, can understand. All other banners follow the same pattern. ${ }^{1}$ Teaching one banner (topic) a day takes me eight days to complete the NEWSTART health awareness talks. They are very effective. I have been using these banners successfully for the last seven years. Whenever visual aids are used, the crowd becomes more interested.

\section{Other Programs}

Other useful and effective resources in health ministry that I have been using are the Better Living filmstrips and slides. There are thirty-four filmstrips with thirty-six pictures each. Each takes about one hour to display and explain. Thus, the filmstrips take thirty-four nights. I show one selected filmstrip each night, occupying as many evenings as are available before the evangelistic meetings proper.

I have been emphasizing temperance, because the target group suffers many illnesses because of the bad habits of their lifestyle. Most of them suffer, not knowing the real cause of their suffering. Proper awareness may prevent them from having serious health problems and promote a long and healthy life.

Hygiene and sanitation are much needed. Living in a filthy environment is the cause of many of the target people's health problems. If proper hygiene and sanitation are provided, many of their felt needs will be met. That will make a bridge to communicate

'E stands for exercise, a necessary component of good health; $W$ for water, both inside and out; $\mathrm{S}$ is for sunlight; $\mathrm{T}$ for temperance; $\mathrm{A}$ for air, vital for health; $\mathrm{R}$ represents the rest and relaxation body and spirit need; and the final T represents trust in God. This program has been taken from the Weimar Institute in California. 
the gospel. The door will be opened.

\section{Educational Contacts}

There is a great and growing need for a good educational system. Some parents have observed that the students who study in government schools have less knowledge than the students who study in Christian schools. Two special areas should be considered: primary school and adult education.

\section{Primary Schools}

The government of India operates a large educational system, but many of the poor or hard-to-reach villages have no access to educational facilities for their children. This provides an opportunity to meet a community need.

Other Christian denominations have schools to meet the educational needs of their children and their converts' children. As a result, their membership has increased. Thus it appears that Christian schools may be an ideal bridge to communicate the gospel message to non Christians.

In the early stages of relations with the target group, the availability of primary schools with coeducation will be of great help to satisfy a felt need. Many of the children who study in the Adventist system of education later become members of the church.

\section{Adult Education}

Another educational bridge is adult education for the illiterate. Literacy programs can open the way to reach many of the target people. When adapted for SDA use, an adult literacy program will also communicate the gospel and prepare target people for church membership.

Vocational training is needed also. For women, tailoring, typing, leather craft, embroidery, basket making, or hat and cap making are possibilities. For men, carpentry, mechanics, welding, electricity, gardening, and small-scale industries such as soap 
making and candle making are options. Vocational training will help the target people to become self-supporting. This will help to meet their felt needs. ${ }^{1}$

\section{Religious Contacts}

For most Folk Hindus, Christianity is a Western religion. It appears associated with Western culture, languages, and practices. It will help the Folk Hindus to know that Christianity was born in Asia (Palestine), and from Judea it spread to Africa, Europe, and other regions in Asia. In fact, the name "Christian" was first used in Syrian Antioch (Acts 11:26).

According to tradition, Christianity was first brought to India by the apostle Thomas. He was followed by a number of other Asian missionaries and appointed church leaders during the next 1,500 years. Recent Christian arrivals from Western countries may still appear Western to Indian eyes. However, by and large, Christianity is well rooted in Indian culture and well adapted to all walks of life in India. This must be shown to them.

The main purpose of this section is to present to receptive Folk Hindus the claims of the gospel in such a way that they will want to give up their beliefs and become Christians. Several religious approaches, based mostly on Jesus and His love, are described.

\section{Jesus: The Only Way to God's Love}

The "One Way Encounter" presents Jesus Christ in a way that conquers hearts. Jesus said, "I am the way" (John 14:6). Peter proclaimed: "Neither is there salvation in any other: For there is none other name under heaven given among men whereby we

${ }^{1}$ On the importance of helping people find solutions to their health, vocation, or other problems as a preparation for their receiving the gospel, see P. G. Hiebert, Anthropological Insights for Missionaries (Grand Rapids, Michigan: Baker Book House, 1985), 24-25. 
must be saved" (Acts 4:12). He is the only true incarnation of God. "God became man" (John 1:14). His name is "Jesus" because He saves His people from sin (Matt 1:23).

Jesus is "the Lamb of God" (John 1:29) who was sacrificed on behalf of the sinners. He seeks His people. He came "to seek out and to save the lost" (Luke 19:10).

God loves His followers. His love is not limited to any particular group but open to all who love and follow Him faithfully. He loved the whole world, as we find in the Bible: "For God so loved the world, that He gave His only begotten Son, that whosoever believeth in Him should not perish but have everlasting life" (John 3:16). There is power in God's love through Jesus to save anyone who accepts Him as his Savior.

In presenting God's love, it is very suitable to dramatize the parables of the prodigal son, the lost sheep, and the lost coin (Luke 15).

God's love is the most powerful tool to reach the Folk Hindus. Jesus is the express image of God (Heb 1:3), revealed through His exemplary life and sacrifice. There is power in the sacrificial Lamb of the world (Jesus) to combat the evil forces that harass Folk Hindus. Unless we present Jesus with greater power than that in which they believe, the Folk Hindus will not accept Him. Therefore, Jesus should be presented as a personal, living, and powerful Savior. This is affirmed by S. D. Ponraj:

The real issue is power among the popular Hindus. They want to experience power in their lives in terms of miracles of healing, casting out demons and answers to their prayers. The power of Jesus Christ should be demonstrated as a greater power than the powers of the gods and goddesses they believe in and worship. In other words, miracles are the powerful evidence of the gospel among the popular Hinduism. ${ }^{1}$

To show the miracles and power of Jesus, the Jesus video is very useful. ${ }^{2}$ The film is described as follows: "There is no tool more powerful in any ministry than the word of God. There is no media more powerful in our world today than film. The Jesus

${ }^{1}$ Ponraj, 144.

${ }^{2}$ Jesus, Inspirational Films, 1989, videocassette. See also http://historicjesus.com. 
video joins the power of both; it is straight Gospel of Luke on film. If a picture is worth a thousand words, this one's worth 83 million."

The Jesus film is the result of thousands of people working together towards one vision: Show the word. A team of 500 Christian scholars and leaders worked together for five years to ensure the film to be archaeologically, historically, and theologically accurate. About this film, Harold Myra of Campus Crusade wrote:

Regardless of their virtues or failings, these ambitious and sometimes dubious efforts to capture Jesus on film have enormous clout in shaping popular understanding of Christ. Like the Gospels themselves, films about Jesus can work on the human psyche in multiple ways. They often dispute popular conceptions of religion and everyone's favorite "right" notions of God, and they sometimes even rearrange the very terrain of the human heart. Such was the obvious power of the medicine that Christian groups like Campus Crusade for Christ embraced it for evangelistic purposes. ${ }^{2}$

Campus Crusade takes great pride in the film, claiming that it has reached an estimated 3 billion viewers in more than 550 languages and effected over 118 million decisions for Christ. Though other ministry-driven Jesus films have been produced, the Jesus film based on Luke's Gospel stands out as the most influential. ${ }^{3}$

\section{In Jesus: Equality for All}

This encounter is extended to combat the problems of the caste system, sex discrimination, and inequalities between rich and poor, low and elite. The Folk Hindus, our target group, are exploited because they are of low caste, illiterate, ignorant, poor, and suppressed by the elite.

In Jesus Christ, God heals all wounds--physical, economical, emotional, spiritual, and racial. He treats all as equals. All are His creatures by creation (John 1:1-10). All

${ }^{1}$ Harold Myra, "Push, Play, Pray, and Watch Jesus Convince Them," Christianity Today, April 5, 1999, 11.

${ }^{2}$ Ibid.

${ }^{3}$ Ibid. 
are created in His image (Gen 1:26). All are of one blood (Acts 17:26). He died for all on the cross (Col 1:20). He came to save all sinners (Luke 19:10).

In Jesus, God bridges the barriers erected by traditional beliefs and practices. In Christ all are privileged to be sons and daughters of God (1 John 3:1). On this topic, Ellen G. White notes:

Divine sonship is not something that we gain of ourselves. Only to those who receive Christ as their Saviour is given the power to become sons and daughters of God. The sinner cannot, by any power of his own, rid himself of sin. For the accomplishment of this result, he must look to a higher Power. ${ }^{1}$

Equality in Jesus is a powerful tool for dealing with the target group. "There is neither Jew nor Greek, there is neither bond nor free, there is neither male nor female; for ye are all one in Christ Jesus" (Gal 3:28). To be in Christ is a great reward that wipes away all traditional notions of inferiority and upgrades humanity to a higher spiritual level. This privilege is not found anywhere else.

To strengthen the belief of the people in Jesus, there should be dramatizations of the stories of Jesus and the Samaritan woman, Jesus and Zachaeus, Jesus healing the lepers, among others. Drama is always an effective teaching device for the target people.

God, revealed through Jesus, proclaimed that His mission was to set captives free (Luke 4:18). He came to put an end also to the captivity of the caste system and untouchability. In God's family, untouchability, color, or caste do not exist. All are one. "Therefore if any man be in Christ, he is a new creature: old things are passed away: behold, all things are become new" (2 Cor 5:17).

Untouchablity creates a deep wound among the affected people. While untouchability was abolished by law, it still clearly exists. We still find that lower-class Folk Hindus are not allowed to enter temples of the high class. Nor are they allowed other privileges.

'Ellen G. White, Sons and Daughters of God (Washington, D.C.: Review and Herald Publishing Association, 1955), 12. 
Even poverty is not an issue on which God could not be trusted. He is the Owner and Provider of all blessings of life (Pss 24:1; 103:4-5). He must be trusted even in poverty. The simplicity, poverty, and humility of Jesus incarnate show us the way. Jesus, living in poverty, could approach all classes of people in His time. He is an example to us on how to approach all classes of people in our time.

\section{The Super Power of God}

In Hinduism people worship a number of gods and goddesses, not out of love but out of fear. They fear that if their deities are not happy, their families will suffer, their business and crops may fail and there will not be prosperity. Therefore, the group performs rites for childbirth, for the child-naming ceremony, for the marriage ceremony, and even for the death ceremony to make appeasement, so that every thing will go well.

In Folk Hinduism, much like in Hinduism, the grip of traditional beliefs and practices has blinded the people. However, they also believe in one super god, the creator, who has much in common with the Christian God.

The Bible is based on a monotheistic principle: "Hear O Israel: The Lord our God is one Lord" (Deut 6:4). He is the Creator God (Gen 1:1). He is the powerful God who brought out His people from the slavery in Egypt (Exod 20:2), who does not accept other gods (vs. 3).

The most remarkable power is exhibited in God's Word. "By the word of the Lord were the heavens made: and all the host of them by the breath of his nostrils... . For he spoke and it was done; he commanded and it stood fast" (Ps 33:6,9). Not so the idol, who, according to Kumaru Nandesan, "has only a mere appearance, but cannot exercise the functions of the organs attached to it. They that make them and they that trust in them are similar to the idol itself." Idol worship is an abomination to the Lord

\footnotetext{
${ }^{1}$ Kumaru Nandesan, From Traditions to Truth (Bombay: Gospel Literature Service, 1996), 76.
} 
God (Deut 7:25). Through Isaiah, God pointed out the futility of idol worship (Isa 44:120). "God is a Spirit: and they that worship him must worship him in spirit and in truth" (John 4:24).

Today evil practices are seen everywhere in the target people. Superstitions, astrology, palmistry, magic, witchcraft, divination, idol worship, and useless rituals are some of their many beliefs and practices under the influence of evil spirits.

The challenge is not to accuse them but to overcome the powers of evil by casting out evil spirits by the victorious power of Jesus. There is power in the blood of the "Lamb" Jesus (Rev 5:12,13). He has promised to send His angels to protect His people (Ps 34:7). They are far superior in strength (Ps 103:20) to any evil spirits.

We must teach new believers that evil spirits are subject to Jesus and His people. Jesus cast out demons (Matt 12:22; Mark 7:26-30; Luke 4:33-36). Therefore, they are a defeated enemy. We must teach the people to rely on God's strength. Ellen White wrote:

Thus God's people, exposed to the deceptive power and unsleeping malice of the prince of darkness, and in conflict with all the forces of evil, are assured of the unceasing guardianship of heavenly angels. Nor is such assurance given without need. If God has granted to His children promise of grace and protection, it is because there are mighty agencies of evil to be met. ${ }^{1}$

Jesus' model of a prayerfull life should be taught to the target group. "And it came to pass in those days, that he went out into a mountain to pray, and continued all night in prayer to God" (Luke 6:12). Once they know that prayer is the "key in the hand of faith to unlock heaven's storehouse, ${ }^{, 2}$ they will never depart from such a relationship with the heavenly Father.

\section{The True Word of God}

Sacred scriptures are not important in Folk Hinduism. The Vedas are not

'Ellen G. White, The Great Controversy (Mountain View, California: Pacific Press Publishing Association, 1950), 513.

${ }^{2}$ White, Steps to Christ, 93. 
generally accepted but are used by the priests only. Even other Hindu scriptures are not likely to be read by Folk Hindus.

The Bible is a unique sacred book. "For the word of God is quick, and powerful, and sharper than any two edged sword, piercing even to the dividing asunder of soul and spirit, and of the joints and narrow, and is a discerner of the thoughts and intents of the heart" (Heb 4:12). It is the Book of God's love, without distinctions, for all people on earth.

The Word of God is the spiritual food needed to strengthen His people for the spiritual warfare against Satan. It is the weapon to be used in the battle against Satan. The target people are very fond of the Word of God. It should be made available to them in their language, Bengali, which is now available through the Bible Society in Calcutta.

Going to a higher plane, ultimate truth exists only in the One who is the Author of truth. Jesus declared: "I am the truth" (John 14:6). He is the perfect image of God, so He can teach truth as no other person can. Jesus is the "Word" (John 1:11), the "Life" (vs. 4), the "Light" (vs. 7), and the "Truth" (vs. 14). To not know Him is to remain in "darkness" (1 John 1:5, 6).

Jonathan Campbell writes that the truth of Jesus

is not religious dogma, an institution or even a religion. Truth is a person, Jesus. We gain hold of what is true through grabbing hold of Jesus. Reality is found in Jesus Christ (Col 2:17). We know truth through our relationship with the author of truth. And it is truth that sets us free $(\mathrm{Jn} 8: 31,32)$. The truth of Jesus is the basis of the way and the way is the embodiment of the truth. ${ }^{1}$

To reach or to know the truth of God one must go through Jesus, for "He is the way and life and truth" (John 14:6). Through Him one can go to the Father: "God has already made a way, so don't run scared or allow yourself to feel hopeless or confused.

${ }^{1}$ Jonathan Campbell, "Releasing the Gospel from Western Bondage," International Journal of Frontier Missions 16 (October-December 1999): 167. 
Simply believe God's word and follow Him to victory."' One must come to God by faith in Jesus to gain "victory over the world" (1 John 5:4-5).

\section{Meeting the Objectives}

The objective of evangelism is to make disciples. To do this, persons must first make a decision, then receive baptism. After entering the body of Christ, postbaptism discipling must take place.

\section{Decision Making}

Folk Hindus have no true sense of personal responsibility. They must be helped to understand that one's life is important, that each person is precious and valuable. Then it will be easier for them to make decisions.

The apostle Paul wrote: "For it is written, As I live, saith the Lord, every knee shall bow to me, and every tongue shall confess to God. So then everyone of us shall give account of himself to God" (Rom 14:11-12).

No matter how illiterate or poor, everyone should know his or her responsibility and accountability. Evaluate the following imaginary dialogue:

Q. Who has to give an account to God?

A. Everyone of us must give an account to God.

Q. Who will kneel before Jesus?

A. Every knee shall bow before Him.

Q. Who will confess to God?

A. Every tongue shall confess before God.

Q. Does "everyone" include me?

A. Yes, me.

'Kenneth Hagin, Jr., “God Has Made a Way,” Faith Today, March 2000, 15. 
Q. Can you read, then, that I, myself, will be accountable to God?

A. Yes, I myself am accountable to God.

The people must be individualized in decision making. They should be able to respond, "Sir, what shall we do?" The answer should be, "Repent, and be baptized in the name of Jesus Christ" (Acts 2:38). This decision was made by the group as one individual; they all believed and were baptized.

\section{Baptism Encounter}

On 18 May 2000, I was making a list of 176 people out of 410 Folk Hindus who had accepted the gospel and bravely stood for Christ. The main leader and the group questioned me as they heard the word "baptism." I told them: "This is your love response to Jesus, it is a sign of the change that has taken place in your heart. You take baptism as an outward sign." "Do you give cow meat for us to eat?" was the most direct inquiry they had. "No, certainly not, you have been informed wrongly; we never do that," I explained. "In fact you will be happy to know that we are vegetarians. How could we do that?" It gave them joy, peace, happiness, and a great relief to have the misconception cleared. Out of the 176 who gave their names, 102 Folk Hindus were baptized. Baptism is a very crucial issue yet it is the joyous and most meaningful occasion, to be celebrated with great joy.

Baptism implies the recognition and acceptance of the Savior's example. Ellen White wrote:

Jesus did not receive baptism as a confession of guilt on His own account. He identified Himself with sinners, taking the steps that we are to take, and doing the work that we must do. His life of suffering and patient endurance after His baptism was also an example to us. ${ }^{1}$

Therefore the decision for baptism should be related to the example of Jesus. Its

${ }^{1}$ White, Desire of Ages, 111. 
significance should be explained as the Bible does it, affirming the spiritual life process of Jesus as an example for us:

Know ye not, that so many of us as were baptized into Jesus Christ were baptized into his death? Therefore we are buried with him by baptism into death; that like as Christ was raised up from the dead by the glory of the Father, even so we also should walk in newness of life. For if we have been planted together in the likeness of his death, we shall be also in the likeness of his resurrection. (Rom 6:3-5)

\section{Follow-Up into Fellowship}

One of the most important steps that must not be neglected is the needed followup to strengthen the new converts. This includes nurturing them into spiritual maturity and discipleship, and also fostering spiritual fellowship that leads to church maturity. Theodore Williams explains:

Fellowship is a blessing that man needs. No one can be a Christian and have the go-it-alone attitude. Any man and God can have any religion but it takes two persons and Christ to have the Christian religion. The grace and love of God are experienced and expressed in fellowship. ${ }^{1}$

The Bible describes this fellowship. The psalmist wrote: "Behold, how good and how pleasant it is for brethren to dwell together in unity" (Ps 133:10). Paul also spoke of this unity.

God is faithful, by whom ye were called unto the fellowship of his Son Jesus Christ our Lord. Now I beseech you brethren, by the name of our Lord Jesus Christ, that ye all speak the same things, and that there be no divisions among you; but that ye be perfectly joined together in the same mind and in the same judgment. (1 Cor 1:9-10)

Williams resonates with Paul: "In Christ there are no caste differences, no class differences, no color differences and no language differences. All the things which divide human beings and separate them ... have been broken down by Christ."

Follow-up activities will strengthen fellowship among the new converts (see Acts

\footnotetext{
'Theodore Williams, "The Path of Harmony," Outreach 27 (October 1988): 7, 8.

${ }^{2}$ Ibid., 8 .
} 
2:43-48). There are simple and correct procedures to this program. A team needs to be assigned to follow-up who will look after the new converts. Some of these activities are house prayer groups, with one or more families; weekly meetings for general Sabbath worship with all the families; and special two-day revival meetings conducted after one month. It is important to train and orientate the elders once every three months to enrich and train them for church leadership. This should be conducted for two days.

For the sake of church youth, it is good to have an annual camp meeting for three to four days. The purpose of the youth camp is to increase unity, cooperation, and affection of the youth. The camp will include nurturing them and training for leadership and career development. This camp also provides an opportunity for social fellowship and choosing an ideal life partner from among fellow believers.

The follow-up team also promotes church planting by involving the members in branch Sabbath schools, singing bands, social activities, and cottage meetings. Evangelistic meetings, conducted with the help and cooperation of the growing members, result in self-propagation and church growth.

An approach such as the one described in this chapter has already proved itself. With further adaptations, it can be used to reach the Folk Hindus of Calcutta and of many other places in India. 


\section{CHAPTER 6}

\section{SUMMARY, CONCLUSIONS, AND RECOMMENDATIONS}

\section{Summary}

The purpose of this study was to develop a strategy to reach the unreached Bengali Folk Hindus of Calcutta.

First, general information on the target group was presented. This included information on their lifestyle and traditional religious beliefs and practices. This enables us to better understand their physical, mental, spiritual, and social felt needs.

A brief review of what Roman Catholic and Protestant churches have done for the Folk Hindus of Calcutta, with their medical, educational, spiritual, and social services, helped us to understand the strengths and weaknesses of mission approaches to the target group. It also helped us to know their resistance and receptivity to the gospel. Further, the barriers of the target group are listed and clarified.

The evangelistic strategy planned to reach this target group in the Calcutta area includes organization of evangelistic teams, tapping existing resources to assist the people to meet their felt needs, and building bridges by means of social, medical, and educational endeavors. Finally, the Folk Hindus of Calcutta should hear the gospel presented to them, with special emphasis on Jesus as the only way to God and as the source of equality for all peoples. The power of God to heal and confront the spirits should also be emphasized, together with the importance of the Bible. Folk Hindus need to be made aware of the need for individual accountability before God, after which they can be led to baptism as an outward sign of their desire to follow Jesus. Once they have 
been baptized, they must be nurtured in fellowship, discipleship, and missionary work.

\section{Conclusions}

The developed strategy is based on my research, interviews, and my field experience. It still needs further development. However, what took place in Arambagh, near Calcutta, is an indication of what will take place through this strategy if it is implemented properly. Many Folk Hindus will come to Christ.

\section{Recommendations}

1. Evangelists as well as lay people should be made aware of this strategy which can be used to reach similar groups of people in other places.

2. The Sections and Unions should prepare and publish materials outlining this type of evangelism and make them available to the field.

3. The Southern Asia Division should consider this strategy for taking the gospel to Folk Hindus. Materials needed to accomplish the work should be translated into the languages used by different groups of Folk Hindus. 


\section{BIBLIOGRAPHY}

Agarkar, A. J. Folk Dances of Mahabharata. Bombay: L. N. Chapekar, 1950.

Agarwal, M. P. Interview by author. Calcutta, 1997.

Agarwala, P. K. Goddesses in Ancient India. New Delhi: Ashinov Publications, 1984.

Aiyar, C. P. The Cultural Heritage of India. Calcutta: Ramakrishna Mission Institute of Culture, 1982.

Amaladass, Anand, ed. Christian Contributions to Indian Philosophy. Madras: Christian Literature Society, 1995.

Amaladoss, Michael. Beyond Inculturation: Can the Many Be One? Delhi: Vidhyajyoti Education and Welfare Society/ISPCK, 1998.

Antoine, Robert, Richard V. de Smet, and J. Neuner, eds. Religious Hinduism: A Presentation and Appraisal. Mumbai: St. Paul's Society, 1996.

Ayrookuzhiel, A. M. A. The Sacred in Popular Hinduism. Madras: Christian Literature Society, 1981.

Baig, Tara Ali. India's Woman Power. New Delhi: S. Chand, 1976.

Bali, D. R. Modern Indian Thought. New Delhi: Sterling Publishers, 1980.

Banerji, Projesh. Folk Dances of India. Allahabad: Kitabistan, 1944.

Bascom, William. "The Forms of Folklore: Prose Narratives." Journal of American Folklore 78 (1965): 3-20.

Belchambers, Mariam. “Growing Up with the Work." Eastern Tidings, May 8, 1941, 14.

Berardo, A. P. Indian Mind. Mangalore: Codiabail Press, 1960.

Bettany, G. T. Encyclopedia of World Religions. New York: Dorset Press, 1988. S.v. "Deities."

Bhatt, S. C., ed. The Encyclopedic District Gazetteers of India. New Delhi: Gyan Publishing House, 1998.

Bishop, Donald H. Indian Thought: An Introduction. New Delhi: Wiley Eastern, 1975. 
Biswas, Sudeep, senior pastor, Baptist Church. Interview by author. Calcutta, November 4, 2000.

Burgess, L. J. "Bengal." Eastern Tidings, May 1916, 6.

. "Bengali Headquarters." Eastern Tidings, August 1916, 7-8.

. "The Blessed Pioneer." Eastern Tidings, May 8, 1941, 2.

. "Calcutta." Eastern Tidings, May 15, 1917, 7.

"Calcutta: Not the City of Joy." http://cesimo.ing.ula.ve/ GAIA/CASES/IND/CAL/ main.html (30 June 2001).

Campbell, Alexander. The Heart of India. New York: Knopf, 1958.

Campbell, Jonathan. "Releasing the Gospel from Western Bondage." International Journal of Frontier Missions 16 (October-December 1999): 167-171.

Chaudhuri, Sukanta. Calcutta the Living City. 2 vols. Calcutta: Oxford University Press, 1990.

Choudhury, N. C. Hinduism: A Religion to Live By. New Delhi: B. I. Publications, 1979.

Choudry, P. Interview by author. Calcutta, October 19, 1999.

Conn, Harvie M. Eternal Word and Changing Worlds: Theology, Anthropology, and Mission in Trialogue. Grand Rapids: Zondervan Publishing House, 1984.

Crook, W. The Popular Religion and Folklore of Northern India. Delhi: Musiram Manoharlal Oriental Publishing, 1996.

Douglas, J. D., and Philip W. Comfort, eds. Who's Who in Christian History. Wheaton, Illinois: Tyndale House, 1992.

D'Souza, H. The Directory of the Archdiocese of Calcutta. Calcutta: Roman Catholic Press, 1999.

Dubois, J. A. Hindu Manners, Customs, and Ceremonies. Oxford: Clarendon Press, 1897; reprint, Delhi: Book Faith India, 1999.

Eastman, Dick. No Easy Road. Grand Rapids, Michigan: Baker Books, 1971.

Erickson, Millard J. Christian Theology. Grand Rapids: Baker Book House, 1998.

Farquhar, J. N. Primer of Hinduism. London: Christian Literature Society, 1911.

Ferris, Robert W., ed. Establishing Ministry Training: A Manual for Programme Developers. Pasadena, California: William Carey Library, 1995.

Fletcher, W. W. "Calcutta English Church.” Eastern Tidings, January 1918, 5. 
Gomes, H. R. Interview by author. Calcutta, October 3, 2000.

Hagin, Kenneth, Jr. “God Has Made a Way.” Faith Today, March 2000, 15.

Harish, Johari. Leela: The Game of Self-knowledge. New York: Cowas, McCann \& Geoghegan, 1975.

Hiebert, P. G. Anthropological Insights for Missionaries. Grand Rapids, Michigan: Baker Book House, 1985.

Hillock, W. M. Involved. Nashville, Tennessee: Southern Publishing Association, 1977.

Horn, Siegfried. Seventh-day Adventist Bible Dictionary. Rev. ed. Washington, D.C.: Review and Herald Publishing Association, 1979.

Houtart, F., and G. Lemerimier. Size and Structures of the Catholic Church in India. Louvain-la-Neuve: Université Catholique de Louvain, 1982.

Ibbetson, Denzil. Religious Life of Indian People. Delhi: Amar Prakashan, 1991.

"Indian Condition." Tortured for Christ, January 1999, 9.

Ingersoll, Olive. "Hydropathic Treatment Room.” Eastern Tidings, May 6, 1941, 5. . "Sanitarium." Eastern Tidings, April 1904, 5.

Jebadurai, Sam. “Prayer.” Jesus Redeems, July 1997, 23.

. Daily Bread. Madras: Sam Jebadurai Publishing, 1992.

Jenson, W. G. Electronic communication to the author, October 3, 2000.

Jesus. Inspirational Films, 1989. Videocassette.

Johnstone, Patrick. Operation World. Carlisle, UK: OM Publishing, 1993.

Jones, J. P. India: Its Life and Thought. New York: Macmillan, 1908; reprint, New Delhi: Rare Books, 1974.

Kane, J. H. Understanding Christian Mission. 3d ed. Grand Rapids: Baker Book House, 1982.

Kanitkar, V. P. Hindu Festivals and Sacraments. New Barnet, UK: By the author, 1984.

Kinsley, David R. The Sword and the Flute. Delhi: Vikas Publishing House, 1976.

Kottunpapallil, G. History of the Catholic Mission in Central Bengal (1855-1986). Shillong: Vendrame Institute, 1988.

Kumar, B. N. Calcutta 1964. Calcutta: Lalvani Publishing House, 1968.

Lall, B. H. "Our Effort in Calcutta." Eastern Tidings, September 1954, 7. 
Lange, O. W. "Good News from Calcutta." Eastern Tidings, June 15, 1952, 41.

Latourette, K. S. A History of the Expansion of Christianity. 7 vols. New York: Paternoster Press, 1971.

Loughborough, J. N. The Great Second Advent Movement: Its Rise and Progress. Washington, D.C.: Review and Herald Publishing Association, 1905.

Mahoney, Ralph. The Shepherd's Staff. Madras: India Bible Literature, 1993.

Maitro, Kalyan, Pastor, Assembly of God Church. Interview by author. Calcutta, November 3, 2000.

Masillamony, R. M. History of Early Seventh-day Adventist Work in Southern Asia. Palayan Kottai: Tiruelveli Diocesan Press, 1982.

Mathew, K. M., ed. Manorama Year Book 1997. Kottayam, Kerala: Malayala Manorama Press, 1997.

Mattan, Joseph, and Sebastian Kim, eds. Mission Trends Today. Mumbai: St. Paul Press, 1997.

McGavran, Donald. Understanding Church Growth. Madras: Evangelical Literature Service, 1982.

Mckenzie, John. The Christian Task in India. London: Macmillan, 1929; reprint, Calcutta: Punthi Pustak, 1994.

Mitra, Asok. Calcutta on the Eve of Her Tercentenary. New Delhi: Abhinav Publications, 1990.

Mondal, S., Folk Hindu converted to Adventism. Interview by the author. Calcutta, November 9, 1999.

Mookerjee, L. G., "A Comprehensive Survey of the Early Work." Eastern Tidings, May $6,1941,7$.

Morgan, K. W. The Religion of the Hindus. New York: Ronald Press, 1953.

Mott, Geoffrey. Calcutta: The City Revealed. New Delhi: Penguin Books India, 1971.

Mukherjee, S. N. Myths and History. Calcutta: Subranrekha, 1977.

Myra, Harold. "Push, Play, Pray, and Watch Jesus Convince Them." Christianity Today, April 5, 1999, 11, 60.

Nair, Thankappan. The People of Calcutta. Calcutta: National Fellowship, n.d.

Nandesan, Kumaru. From Traditions to Truth. Bombay: Gospel Literature Service, 1996.

Narayana, V. N. “Day of Homage and Hope." Bhavan's Journal, April 16-30, 2001, 23. 
Neil, Stephen. Concise Dictionary of the Christian World Mission. New York: Abingdon Press, 1971.

The New Book of Knowledge. Chicago: Grolier, 1975. S.v. "Calcutta."

O'Flaherty, Wendy Doniger. Karma and Rebirth in Classical Indian Traditions. Delhi: Motilal Banaras, 1983.

Ponraj, S. Devasagayam. An Introduction to Missionary Anthropology. Madras: Mission Educational Books, 1993.

Preston, James J. Cult of the Goddess. New Delhi: Vikas Publishing House, 1980.

Price, M. T. Christian Mission and Oriental Civilization: A Study in Culture Contact. Shanghai: By the author, 1924.

Radice, William, ed. Swami Vivekananda and the Modernization of Hinduism. New Delhi: Oxford University Press, 1998.

Raj, Samuel A. Attempt Great Things. Calcutta: SAILEE, 1993.

Ray, Niharranjan. History of the Bengali People. Calcutta: Orient Longmans, 1994.

Sam, Victor, and Vikash Pann. Interview by author. Calcutta, November 5, 2000.

Sanders, J. Oswald. Effective Evangelism: The Divine Art of Soul Winning. Bombay: STL Books, 1982.

Schwarz, Richard W., and Floyd Greenleaf. Light Bearers: A History of the Seventh-day Adventist Church. Boise, Idaho: Pacific Press Publishing Association, 2000.

Seventh-day Adventist Encyclopedia. Edited by Don. F. Neufeld. Washington, D.C.: Review and Herald Publishing Association, 1976. S.v. "India."

Shah, K. T. The Splendor That Was India. Bombay: D. B. Taraporevala Sons and Company, 1930.

Singh, R., a Folk Hindu. Interview by author. Calcutta, September 19, 1999.

Sogaard, Viggo. Media in Church and Mission Communicating the Gospel. Pasadena, California: William Carey Library, 1993.

Spalding, A. W. Origin and History of Seventh-day Adventists. 4 vols. Washington, D.C.: Review and Herald Publishing Association, 1962.

Spicer, W. A. After One Hundred Years. Washington, D.C.: Review and Herald Publishing Association, 1944.

Thomas, Paul. Epics, Myths, and Legends of India. Bombay: D. B. Taraporevela Sons, n.d. 
Vasantharaj, Albert S. A Portrait of India. Madras: Church Growth Association of India, 1995.

Wagner, C. P., Peter Stephen, and Wilson Mark. Praying through the 100 Gateway Cities of the 10/40 Window. Seattle, Washington: YWAM Publishing, 1995.

White, Ellen G. Acts of the Apostles. Washington, D.C.: Review and Herald Publishing Association, 1956. 1988.

. Better Living for Your Home. Altamont, Tennessee: Harvestime Books,

. Education. Mountain View, California: Pacific Press, 1953.

. Gospel Workers. Washington, D.C.: Review and Herald Publishing Association, 1948.

. The Great Controversy. Mountain View, California: Pacific Press Publishing Association, 1950.

. The Ministry of Healing. Mountain View, California: Pacific Press Publishing Association, 1942.

. Sons and Daughters of God. Washington, D.C.: Review and Herald Publishing Association, 1955.

. Steps to Christ. Washington, D.C.: Review and Herald Publishing Association, 1981.

Whitehead, H. The Religious Life of India. Calcutta: Association Press, 1921.

Wilkins, W. J. Hindu Mythology. Calcutta: Rupa and Co., 1973.

Williams, Theodore. "The Path of Harmony." Outreach 27 (October 1988): 7-8.

World Book Encyclopedia. 1996. S.v. "Calcutta."

Yardi, Kalyan, Vicar of Calcutta Parish, Church of North India. Interview by author. Calcutta, November 3, 2000. 


\section{VITA}

Personal Background

Name

Eric Kujur

Date of Birth

October 11,1944

Place of Birth

Allahabad, Uttar Pradesh, India

Marriage

April 28, 1975

Wife's Name

Mercy Tirkey

Children

Melinda Vandana Kujur (24)

Eddie Erdan Kujur (19)

Academic Experience

1964

Shankari High School, Ranchi, India

1974

Bachelor of Liberal Arts, Spicer Memorial College, Pune, India

1980

Master of Arts, S.D.A. Theological Seminary, Silang, Philippines

1996-2001

Doctor of Ministry degree, Andrews University Extension Spicer Memorial College, Pune, India

Professional Experience

1970

Assistant Farm Manager, Spicer Memorial College, Pune, India

1974

Farm Manager, Seventh-day Adventist School, Kunti, Ranchi, India

$1975-1979$

Farm Manager and Bible Instructor at the Bible Seminary of

S.D.A. Junior College, Roorkee, India

1981-1983

Farm Manager, Bible Teacher, and Associate Church 
Pastor, S.D.A. Junior College, Roorkee, India

$1984-1987$

$1987-1989$

$1989-1990$

1990-1991

1992-1993

$1994-2000$

2000-
Bible Teacher, Church Pastor, and Farm Manager, Raymond Memorial High School, Falakata, India

Bible Teacher, Church Pastor, and Farm Manager, S.D.A. High School, Roorkee, India

Headmaster, S.D.A. High School, Lucknow, India

Church Pastor, S.D.A. Church, Delhi

Director of Agricultural Project, Raymond Memorial High School, Falakata, India

Pastor and Director of Metro Evangelistic Region, Calcutta, India

Executive Secretary, East India Section of S.D.A., Ranchi, India 